\title{
Религия и искусство репрезентации: символизм зооморфного стиля в Центральной Азии
}

\author{
Лаура Г. Ерекешева \\ Казахский Национальный университет им. аль-Фараби, \\ Республика Казахстан
}

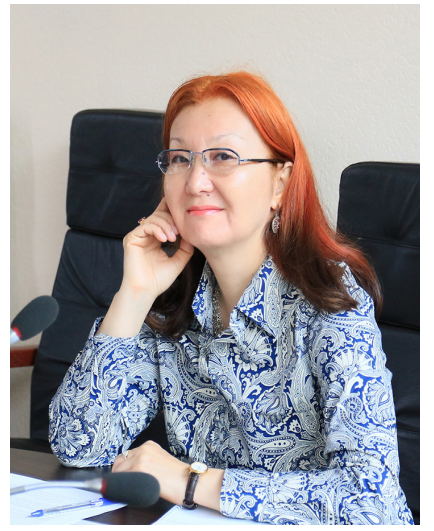

Зооморфные изображения, найденные на значительном пространстве евразийского континента от Восточной Азии, Южной Сибири, Монголии, Тувы, Алтая, Казахстана до Поволжья, Приуралья, Кавказа, Причерноморья и относящиеся к сакской/скифской культурам, обладают как общими типологическими закономерностями, так и собственной спецификой. Как известно, сакский/скифский зооморфный стиль оказал исключительное влияние на культуру народов Центральной Азии, отголоски которого, словно эхо веков, можно проследить в материальной культуре и в настоящее время.

В статье рассматриваются вопросы символической репрезентации религиозных представлений и верований на примере зооморфного стиля в искусстве Центральной Азии второй половины - середины I тысячелетия до н. э. В географическом и хронологическом плане анализу подвергаются артефакты и находки, относящиеся к так называемому сакскому периоду (оленные камни и херексуры, элементы конской упряжи, воинского снаряжения, ювелирные украшения и искусство в зооморфном стиле), найденные в Туве, на Алтае, в Семиречье.

В методологическом плане данная репрезентация изучается на основе кросс-дисциилинарного подхода, с использованием элементов теории структурного функционализма в теоретической социологии религии (Т. Парсонс), семиотического подхода в культуре (Ю. Лотман) в их соотношении с уровнями развития и религиозными верованиями. Показывается, что в зооморфном стиле могут отражаться (в разной степени) элементы, относящиеся к различным религиозным верованиям, спектр которых широк - солярные культы, культы Неба, культ предков, зооморфные культы, магия, тотемизм, шаманизм.

Делается вывод, что зооморфный стиль в искусстве и материальной культуре является синергетической репрезентацией древнейших и базовых религиозных представлений в целом; результатом своеобразной трансформации знака, через информацию и смысл, в символ.

Ключевые слова: символическая репрезентация; религиозные представления; сакская культура; скифская культура; солярный культ; культ предков; тотемизм; шаманизм; зооморфный стиль; Центральная Азия; Тува; Аржан; Алтай; Пазырыкский курган; Семиречье

\section{Для цитирования:}

Ерекешева Л. Г. Религия и искусство репрезентации: символизм зооморфного стиля в Центральной Азии // Новые исследования Тувы. 2021, № 1. С. 6-29. DOI: https://www.doi.org/10.25178/nit.2021.1.1

\footnotetext{
Ерекешева Лаура Гибратовна - доктор исторических наук, ассоциированный профессор факультета востоковедения Казахского Национального университета им. аль-Фараби (КазНУ им. аль-Фараби). Адрес: г. Алматы, ул. Карасай-батыра, 95/53, каб. 511. Тел.: +7 701629 3007. Эл. адрес: laura.erekesheva@kaznu.kz, laurayerek@gmail.com
}

YEREKESHEVA, Laura Gibratovna, Doctor of History, Associated Professor, Faculty of Oriental Studies, al-Farabi Kazakh National University. Postal address: Almaty, 95/53 Karassay-Batyr Street, office 511. Tel.: +7 701629 3007. Email: laura.erekesheva@kaznu. kz; laurayerek@gmail.com ORCID ID: 0000-0002-2610-0187 


\title{
Religion and the Art of Representation: Symbolism of Zoomorphic Style in Central Asia
}

\author{
Laura G. Yerekesheva \\ Al-Farabi Kazakh National University, Republic of Kazakhstan
}

Zoomorphic images found in the large area of the Eurasian continent stretching from East Asia, South Siberia, Mongolia, Tuva, Alta and, Kazakhstan to the Volga region, the Urals, the Caucasus, the Black Sea region and associated with the Saka / Scythian cultures have both common typological patterns and their own specificity. It is well known that the Saka / Scythian zoomorphic style had an exceptionally strong impact on the cultures of the peoples of Central Asia, the echoes of which, through centuries, can be traced in the material culture of today.

The article examines the issues of symbolic representation of religious ideas and beliefs in zoomorphic style of Central Asian art from the middle to second half - of the 1st millennium BCE. Geographically and chronologically, the article focuses on artifacts and finds related to the so-called Saka period, such as reindeer stones and khereksurs, elements of horse harness, military equipment, jewelry and art in a zoomorphic style found in Tuva, Altai, and Semirechye.

Methodologically, this representation is studied on the basis of a cross-disciplinary approach, using elements of the theory of structural functionalism in the theoretical sociology of religion (T. Parsons), and of a semiotic approach in culture (Yu. Lotman), both taken in their relation to levels of development and religious beliefs. It is shown that the zoomorphic style can reflect (to varying degrees) elements related to a most diverse multitude of belief systems, such as solar cults, Heaven cults, ancestor cults, zoomorphic cults, magic, totemism, and shamanism. It is concluded that the zoomorphic style in art and material culture is a synergistic representation of the most ancient and basic religious concepts in general; the result of a transformation of a sign, through information and meaning, into a symbol.

Keywords: sign; symbolic representation; religious beliefs; Saka culture; Scythian culture; solar cults; ancestor cult; totemism; shamanism; zoomorphic style; Central Asia; Tuva; Arzhan burial mounds; Altai; Pazyryk burial mound; Semirechye

\section{For citation:}

Yerekesheva L. G. Religion and the Art of Representation: Symbolism of Zoomorphic Style in Central Asia. New Research of Tuva, 2021, no. 1, pp. 6-29. (In Russ.). DOI: https://www.doi.org/10.25178/nit.2021.1.1

\section{Введение}

Сакский/скифский стиль, концептуально определяемый в контексте единства своеобразной «триады» - воинского снаряжения, конской упряжи и «зооморфного» искусства, был исключительно ярко представлен у народов, проживавших на обширном поясе Евразии в первом тысячелетии до нашей эры. Также определяемый как скифо-сибирский, «звериный» или зооморфный «большой стиль» ${ }^{\text {, }}$ он получил широкое распространение на значительном пространстве евразийского континента от Восточной Азии, Тувы, Южной Сибири, Монголии, Алтая, Казахстана до Поволжья, Приуралья, Кавказа, Причерноморья, Приднепровья. Достигнув своего пика в середине I тыс. до н. э. в так называемый скифский/сакский период (VII-III вв. до н. э.)2, данный стиль оказал исключительное влияние на культуру народов Центральной Азии, отголоски которого, словно эхо веков, можно обнаружить в материальной культуре и искусстве и в настоящее время.

Если обратиться только к так называемому «восточному» ареалу распространения зооморфного стиля, точнее, к его «сердцевине» и истокам, то можно отметить исключительно широкое разнообразие

${ }^{1}$ По мнению В. А. Кореняко, искусство скифо-сибирского звериного стиля можно отнести к т. н. «большим стилям», поскольку «территория его распространения выходит далеко за пределы не только любого конкретного этноса, но и этнокультурной общности, более того - за пределы ареала одной языковой семьи» (Кореняко, 2002: 149).

${ }^{2}$ В данной работе используются в целом устоявшиеся хронологические рамки скифского/сакского периода, при этом не детализируются так называемый раннескифский и собственно скифский периоды. Подробнее об этом см.: Шульга, 2013. 
различных материальных культур, в большей или меньшей степени связанных друг с другом: в Туве (в Уюкской котловине, Аржан-1-2, алды-бельская, уюкско-саглынская), Южной Сибири (тагарская культура, VII-III вв. до н. э.), на Алтае (пазырыкская, большереченская), в Казахстане - центральном (Тасмола), восточном (Чиликты), юго-восточном (Бесшатыр) и южном (сакские культуры Семиречья, курганы Иссыкские, Молалы, Шубарат, нижнего течения Сырдарьи), в Кыргызстане (западный ТяньШань, долина рек Чу и Талас, озеро Иссык-Куль (Барсакаун) (Kilunovskaya, Semyonov, 2019: 44; Ховалыг и др., 2019; Кисель, 2019; Руденко, 1953; Акишев, 1978: 6; Frumkin, 1964: 18; Нурмуханбетов, Тулегенов, Иванов, 2019).

Примечательно, что те или иные культуры, как например, уюкская в Туве распространялась также и на Западную Монголию (так называемая чандманьская культура) (Кореняко, 2002: 10), граница Тувы и Монголии вообще представляла собой «контактную историко-культурную зону» в виде монгун-тайгинской культуры (Килуновская, 2018: 35), а пазырыкская культура оказала влияние на Монгольский Алтай (Turbat, Batsukh, 2015: 33). Проявления звериного стиля обнаруживают себя и в Восточном Туркестане (современный Синьцзян-Уйгурский автономный район (СУАР) Китайской Народной Республики), северном Китае, в частности, во Внутренней Монголии, а также на территории современного северного Афганистана (Кореняко, 2002; Shao, 2000; Cambon, Jarrige, 2006; Сарианиди, 1983).

Безусловно, столь обширное распространение зооморфного стиля, выдержанного в едином концептуальном ключе, ставит вопросы о типологических закономерностях, с одной стороны, а также о высокой роли экономического и культурного взаимодействия и, соответственно, взаимовлияния культур - с другой. В последнем случае необходимо отметить также и такие неизбежные процессы как унификация, а также культурная адаптация и специфика, поскольку в условиях широкого географического распространения всегда происходят процессы локализации того или иного культурного феномена.

Основные характеристики скифо-сибирского зооморфного стиля, известные науке начиная с так называемой Сибирской коллекции Петра I (Руденко, 1962), исследователи сводят к следующим характеристикам: «анимализм, относительно небольшой размер (за исключением петроглифов и оленных камней), особый художественный стиль (декоративность, условность, схематизм, выражающийся в особом изображении тела, поз животных, особых поворотах головы, сценах «терзания» одних животных другими, т. д.)» (Кореняко, 2002: 6-7); «разнообразие приёмов в изображении животных в зависимости от формы того предмета, в которое должно быть вложено изображение животного, замечательное искусство композиции» (Руденко, 1962: 29-30).

Единый концептуальный взгляд, характерный для скифо-сибирского стиля, мог определяться различными факторами, среди которых экономические изменения, происходившие в период массового освоения пространства Евразии различными племенными союзами на протяжении первого тысячелетия до нашей эры, играли важную роль. Кочевой образ жизни в качестве важной социальноэкономической парадигмы, а также его взаимодействие с оседлым миром, безусловно, оказывал влияние на основные контуры данного стиля - всадническую культуру, окружающее природное пространство, в частности, животный мир, мобильность и экспрессию. Поэтому неудивительными предстают находки, выполненные в едином стиле, но географически «разбросанные» в различных культурно-исторических ареалах. Очень ярко это можно увидеть на примере артефактов, найденных в 1978-1979 гг. на севере Афганистана (Тилля-Тепе) советско-афганской археологической экспедицией под руководством В. И. Сарианиди, которые показали, что традиции кушан «берут начало в скифоалтайском мире», при этом «казалось бы, расстояния, разделяющие Афганистан и Сибирь, исключают возможность сходства, однако весь комплекс находок этой могилы с несомненностью свидетельствует об обратном. ... Многие изделия Сибирской коллекции находят близкие соответствия, если не копии, среди погребальных украшений могил Тилля-Тепе» (Сарианиди, 1983: 78, 39-40).

Зооморфный стиль, или «искусство экспрессивных деформаций» (Кореняко, 2002: 150-151), как и любой другой стиль в целом, неразрывно был связан с существовавшим образом жизни, то есть культурой племен, среди которых он получил распространение. Если исходить из широкого понимания культуры как образа жизни, связанного с различными измерениями жизни человека и социальных групп, а не только с каким-либо одним, то становится необходимым обращение к так называемому холистическому подходу. При данном подходе любые аспекты культуры как, например, 
экономический тип хозяйствования племен, неразрывно переплетен со всеми иными, в частности, с господствовавшими религиозными представлениями и идеологией того периода.

Поэтому закономерно встает вопрос о том, что единый в концептуальном плане стиль мог определяться, помимо экономического, также и комплексом иных факторов, в первую очередь, религиозным.

Каким образом религиозные представления были связаны с зооморфным стилем и почему они оказались устойчивыми как в хронологическом, так и географическом плане? Данные вопросы являются важными для понимания специфики религиозных воззрений людей древности, а также эволюции религиозных представлений в целом. Зооморфное искусство представляет замечательную возможность изучить данные процессы на примере артефактов, относящихся к различным культурноисторическим ареалам скифо-сибирского стиля. В частности, интерес представляют артефакты, найденные относительно недавно, в конце XX - начале XXI века в Туве (курганы Аржан-1, Аржан-2), которые корректируют наше представление о хронологических рамках зооморфного стиля, расширяя его до IX в. до н. э., одновременно фиксируя его географический центр и, соответственно, границы его влияния. Как отмечают исследователи, «наиболее вероятная дата его (кургана Аржан-1. - Л. E.) сооружения определена 788 г. до н. э., а при 95\%-ом доверительном интервале - от 807 до 772 г. до н. э. ... “Царский”| курган этой культуры Аржан-2, датированный второй половиной VII в. до н. э., безусловно, относится к завершающей фазе горизонта» (Чугунов, 2020: 229-230).

Поэтому закономерным предстает положение о том, что север Центральной Азии - Тува, Горный Алтай и Западная Монголия являются прародиной скифов (Семенов, 2011).

Исходя из вышеизложенного, основными задачами настоящей статьи являются следующие: 1) в методологическом плане рассмотреть зооморфный стиль в искусстве как своеобразный элемент эволюции религиозных представлений на базовом органическом уровне, обозначающем переход от знака к символу; 2) проанализировать символическую репрезентацию в зооморфном стиле в контексте преемственности и дальнейшего развития религиозных представлений, отражения принципа сакральности. Иными словами, представляется важным определить - каким образом в искусстве, относящемся к зооморфному стилю, были представлены элементы и символика религиозных представлений более ранних периодов развития, начиная с древних - солярных - символов.

Данное изучение будет проводиться на примере артефактов, относящихся к различным культурноисторическим ареалам Центральной Азии, на основе сопоставления с материалами уюкской культуры (курганы Аржан в Республике Тыва, Российская Федерация). Подобного рода постановка вопроса неизбежно связана с использованием кросс-дисциплинарного подхода, на стыке теоретической социологии религии, истории искусства, культурологии с использованием достижений и открытий, сделанных в археологии, особенно в последние десятилетия.

\section{Методология}

В методологическом плане изучение религиозных верований через символическую репрезентацию представляется плодотворным проводить с учетом наработок, проведенных в теоретической социологии религии, в частности, теории структурного функционализма (Т. Парсонс), а также семиотического подхода в культуре (Ю. Лотман). Возникающая синергия отдельных элементов, разработанных в каждой из данных теорий, творчески переработанная и адаптированная к теме исследования, может пролить свет на понимание зооморфного стиля как своеобразной квинтэссенции символа, смысла, знака, с одной стороны, а также формы и функции - с другой.

Исходное положение Т. Парсонса о четырех системах (биологической, индивидуальной, социальной, культурной) и выполняемых ими функциях (Parsons, 1985) отчетливо коррелируется с основными уровнями развития любых систем, а именно - органическим, когнитивным, реляционным, институциональным. Не вдаваясь в рамках настоящей статьи подробно в детали сугубо теоретического анализа, отметим лишь следующее. Каждая система по мере своего развития и усложнения закономерно будет включать в себя все данные уровни, начиная с органического (или базового) и заканчивая институциональным (или высшим, всеобъемлющим). Иными словами, соотношение между системой и уровнем будет носить как горизонтальное, так и вертикальное (глубинное) измерения (таблица 1). 
Таблица 1. Соотношение «Система/Уровень - Уровень» на примере биологической системы. Table 1. The System/Level - Level correlation in a biological system.

\begin{tabular}{|l|l|}
\hline \multicolumn{1}{|c|}{ Система/Уровень } & \multicolumn{1}{c|}{ Уровень } \\
\hline (4) Культурная система & (4) Институциональный \\
\hline (3) Социальная система & (3) Реляционный \\
\hline (2) Индивидуальная система & (2) Когнитивный \\
\hline (1) Биологическая система & (1) Органический \\
\hline 1.4 Институциональный уровень & \\
\hline 1.3 Реляционный & \\
\hline 1.2 Когнитивный & \\
\hline 1.1 Органический & \\
\hline
\end{tabular}

Прим.: Выделенные курсивом пункты 1.1-1.4 показывают так называемое «глубинное» измерение, или уровни, каждой системы, в данном случае биологической системы.

Данная корреляция находит свои параллели и в другой значимой теории - семиотическом подходе применительно к культуре, концепте семиосфере, плодотворно разрабатывавшемся Ю. Лотманом (Лотман, 1999). Выделение данным исследователем знака, смысла и символа в качестве определяющих для понимания концепта семиосферы в целом, предоставляет возможность в контексте данной темы задаться вопросом о том, каким образом знаки, значения, смыслы и символы могут соотноситься с системами, оказывающими влияние на людей и социальные группы, а также с уровнями, определяющими их развитие и усложнение.

Данный вопрос имеет самое непосредственное отношение к настоящей теме, поскольку помогает понять значение и смысл передаваемых репрезентаций, «закодированных» сообщений и посланий, выраженных в искусстве на определенном этапе развития человечества. Особенно большое значение это может иметь при анализе религиозных значений и смыслов давно прошедшего времени, оставившего нам в наследство как правило отрывочные, но исключительно убедительные и словно «живые» образцы творческого духа и систему взглядов и верований людей прошлого.

Поэтому неудивительно, что система (религиозных) взглядов, имеющих определенное значение и смысл, и выраженных через определенные символы (в том числе и особенно в искусстве), должна рассматриваться комплексно в связи с отмеченными выше уровнями - органическим, когнитивным, реляционным, институциональным, ведь в своем развитии от более низкого к более высокому уровню система репрезентации также должна пройти аналогичный путь.

Данное соотношение/корреляция между отмеченными выше системами и уровнями, с одной стороны, и элементами семиотического понимания мира, с другой, можно представить в следующем виде (таблица 2).

Таблица 2. Семиотическое измерение «Система/Уровень - Семиосфера» на примере биологической системы.

Table 2. Semiotic structure of 'System/Level - Semiosphere' in a biological system.

\begin{tabular}{|l|l|}
\hline \multicolumn{1}{|c|}{ Система/Уровень } & \multicolumn{1}{c|}{ Уровень/Семиосфера } \\
\hline (4) Культурная система & (4) Институциональный \\
\hline (3) Социальная система & (3) Реляционный \\
\hline (2) Индивидуальная система & (2) Когнитивный \\
\hline (1) Биологическая система & (1) Органический \\
\hline 1.4 Институциональный уровень & 1.4 Символ \\
\hline 1.3 Реляционный & 1.3 Смысл \\
\hline 1.2 Когнитивный & 1.2 Информация \\
\hline 1.1 Органический & 1.1 Знак \\
\hline
\end{tabular}

Как видно из таблицы 2, каждому уровню биологической системы соответствует определенный «семиотический» элемент: органическому уровню - знак, когнитивному - информация, реляционному - смысл, и институциональному - символ. Это может означать, что развитие системы, в данном случае, биологической, должно претерпевать определенное усложнение в сторону трансформации некоего определенного знака в символ. Иными словами, простое представление оп- 
ределенного образа в качества знака проходит путь к своей институционализации, когда какой-либо образ перестает быть просто знаком, но, через повторение информации на когнитивном уровне и закрепление определенного смысла/значения на реляционном, превращается в некий символ на институциональном уровне, причем, символ разделяемый, то есть одинаково значимый для всех членов тех или иных социальных групп.

В случае с религией, определенный разделяемый символ может охватывать значительные пространства. При этом сам символ неизбежно должен включать в себя все «предшествующие» элементы знак, информацию, смысл, т. е. быть их своеобразной квинтэссенцией, в сжатом и переработанном виде представляющем их. В этом смысле знак, информация, смысл и символ будут также являться частью того или иного уровня (например, органического, в случае с биологической системой).

Данный тезис хорошо иллюстрируется на примере зооморфного стиля и религиозныхпредставлений, связанных с ним (таблица 3).

Таблица 3. Соотношение «Система/Уровень - Уровень/Семиосфера - Репрезентация - Религиозные представления» на примере биологической системы.

Table 3. The correlation of 'System/Level - Level/Semiosphere - Representation - Religious ideas' in a biological system.

\begin{tabular}{|c|c|c|c|}
\hline Система/Уровень & Уровень/Семиосфера & Репрезентация & $\begin{array}{c}\text { Религиозные } \\
\text { представления }\end{array}$ \\
\hline (4) Культурная система & (4) Институциональный & & \\
\hline (3) Социальная система & (3) Реляционный & & \\
\hline $\begin{array}{l}\text { (2) Индивидуальная } \\
\text { система }\end{array}$ & (2) Когнитивный & & \\
\hline $\begin{array}{l}\text { (1) Биологическая } \\
\text { система }\end{array}$ & (1) Органический & & \\
\hline $\begin{array}{l}1.4 \text { Институциональный } \\
\text { уровень }\end{array}$ & 1.4 Символ & $\begin{array}{l}\text { 1.4. Символическое } \\
\text { изображение животных, } \\
\text { птиц, зооморфный стиль в } \\
\text { искусстве }\end{array}$ & \multirow{4}{*}{$\begin{array}{l}1.4-1.1 \\
\text { Шаманизм, магия, } \\
\text { анимизм, тотемизм, } \\
\text { фетишизм, } \\
\text { зооморфные культы; } \\
\text { культ предков, } \\
\text { солярные, лунарные, } \\
\text { астральные культы, } \\
\text { культы Неба, Земли, } \\
\text { Воды }\end{array}$} \\
\hline 1.3 Реляционный & 1.3 Смысл & $\begin{array}{l}\text { 1.3. Изображения } \\
\text { животных, птиц с } \\
\text { определенным смыслом } \\
\text { (солярные знаки, солярные } \\
\text { «лодки» и др.) }\end{array}$ & \\
\hline 1.2 Когнитивный & 1.2 Информация & $\begin{array}{l}\text { 1.2. Изображения } \\
\text { животного, птичьего, } \\
\text { растительного мира }\end{array}$ & \\
\hline 1.1 Органический & 1.1 Знак & $\begin{array}{l}1.1 \text { Петроглифы, } \\
\text { изображения солнца, луны, } \\
\text { звезд, неба, земли }\end{array}$ & \\
\hline
\end{tabular}

Как видно из таблицы 3, определенному семиотическому элементу соответствует тот или иной вид репрезентации. Например, к знаку можно отнести петроглифы, графическое начертание определенных объектов окружавшего человека мира; к информации - в целом изображения конкретных животных/ птиц; к смыслу - включение определенных элементов при изображении животных и придание им 
некоего закодированного смысла/значения. Наконец, к символу можно отнести трансформацию реалистичного изображения животных в сферу сугубо символическую, когда символы полностью доминируют и при этом заключают в себе знаки, несут определенную информацию, имеют некий смысл.

К символической репрезентации можно отнести зооморфный стиль в целом, который являет собой своеобразную квинтэссенцию заложенных в нем знаков, информации, смыслов и символов. И если в данном отношении зооморфный стиль можно уподобить своеобразной летописи, вместившей в себя хроники прошлого и отдающей им дань, то закономерно возникает вопрос о выявлении данных хроник, элементов прошлого. Рассмотрим этот вопрос далее на примере артефактов, относящихся к зооморфному стилю.

В завершение данного краткого методологического обзора хотелось бы также отметить, что любые символические репрезентации неизбежно будут коррелироваться с религиозными преставлениями и верованиями как их своеобразное выражение. В случае с репрезентацией в биологической системе, отражающей развитие человечества в далеком прошлом, религиозные представления на органическом уровне предстают в совокупном виде самых различных взаимосвязанных верований шаманизма, магии, анимизма, тотемизма, фетишизма, зооморфных, солярных, лунарных, астральных культов, культов предков, Неба, Земли, Воды. Религиозное содержание символических репрезентаций помогает лучше понять их специфику, устойчивость, распространение, охват, что, в случае с зооморфным стилем может пролить свет на его широкое распространение в Евразии и относительную устойчивость в хронологическом плане.

\section{Зооморфный стиль: символическая репрезентация и преемственность сакральности}

Как было отмечено выше, зооморфный стиль можно считать символической репрезентацией, включающей в себя знак, информацию, смысл/значение и символ. Поэтому символическое изображение животных и птиц в зооморфном стиле может вмещать в себя также определенные смысловые символики предшествующих периодов.

В данном инклюзивном формате смысловые интерпретации напрямую связаны с религиозными представлениями, которые, если исходить из корреляции, отмеченной в таблице 3, должны включать в себя различные элементы. Можно предположить поэтому, что в зооморфном стиле могут отражаться (в разной степени) элементы, относящиеся к различным религиозным верованиям, спектр которых широк - солярные, лунарные, астральные культы, культы Неба, Земли, Воды, культ предков, зооморфные культы, магия, анимизм, тотемизм, фетишизм, шаманизм.

К важным элементам относятся знаки, имеющие определенное значение и смысл - обращение к божественным силам окружавшего мира, благопожелательные, защищающие, охраняющие. К наиболее ранним и ярко выраженным можно отнести «обращение» человека к солярным, астральным светилам (божествам), к животным, значимым для жизни человека, и их включение в свою картину мироздания, замечательно выраженную через искусство рисования на «каменных писаницах» или каменных книгах, по выражению академика А. П. Окладникова (Окладников, 1989).

Например, в петроглифах, найденных в Сибири, в частности, в долинах рек Олекмы и Амура, А. П. Окладников выделял особую традицию со своей специфической семантикой, сюжетами, хронологией - изображения лосей, антропоморфных фигур с личинами, масками, космическими солярными, астральными знаками, солярными лодками с животными и сидящими фигурами (Окладников, Мазин, 1976: 8). При этом в наскальных рисунках наряду с собственно изображениями солнца, луны, звезд, изображались определенные животные, как правило, лоси и олени, которые являлись объектом поклонения и со временем стали символизировать солнце в целом. Например, в IV-III тыс. до н. э. солнце изображалось уже не только в сугубо геометрическом виде (окружность как знак), но и в виде наиболее значимых для человека животных - лосей или оленей, плывущих на лодке/ладье по небу и исчезающих в воде под землей, подобно тому как солнце за день проходит путь по небосводу с востока на запад (там же).

Изображения так называемых солярных «лодок» являются важным маркером изменений, происходивших в религиозных представлениях людей древности, в ходе которых вместо изображений божественных сил (светил, в частности, солнца), через информацию об окружающем человека мире произошла трансформация знака и наделение его определенным смыслом и значением. В данном 
случае изображение животного стало иметь уже иной смысл - не только как конкретное животное (лось или олень), но также и как солнечное божество, представленное в виде того или иного животного. Поэтому можно отметить расширение смыслового ряда, когда к имеющемуся изначальному смыслу определенного животного (животное-тотем) добавлялся новый - животное-солнце. В случае с наскальными рисунками из Сибири, такими важными «системообразующими» для обществ животными были лоси (будучи самыми большими и сильными, они имели исключительное значение для выживания социальных групп в древности) и олени. Впоследствии, в других географических ареалах данная сакральность переносилась и на других животных, например, лошадь, быка, барана, верблюда.

Основываясь на вышеотмеченной методологии, уместно предположить, что сакральность того или иного животного со временем не только не исчезла, но даже усилилась, при этом трансформируясь в дальнейшем и закрепляясь в виде определенного символа. Рассмотрим это далее на примере сакральности солярных и других религиозных представлений, и их отражение в символике зооморфного стиля.

Курганы-херексуры и оленные камни. Зооморфный стиль получил распространение в декоративноприкладном искусстве, связанном с воинским снаряжением, конской упряжью, а также в ювелирном искусстве, в искусстве монументальных памятников - курганов-херексуров и оленных камней.

Из перечисленных видов искусства последний - херексуры ${ }^{1}-$ являются менее изученными. В композиционном плане они состояли, как правило, из наземного кургана в центре, окруженного внешними кольцами/оградами, с отходящими от центра радиальными лучами, включавшими также оленные камни. Данная композиция херексуров, широко распространенных в Монголии, Забайкалье, Алтае и Туве, позволила Ю. С. Худякову определить их как «культуру херексуров и оленных камней» (цит. по: Чугунов, 2002: 142). В рамках настоящей темы интерес представляет их соотнесение с солярным культом - культом Солнца, принимая во внимание круговые формы и радиальные линии. Как отмечают исследователи, херексуры Тувы являются символами Солнца, отражающими его основную сущность - движение (Килуновская, Семенов, 2019: 34).

Считается, что оленные камни, найденные в Туве, Забайкалье, Монголии (VII-III вв. до н. э.), являлись посмертными памятниками «в честь наиболее знатных лиц, племенных вождей и выдающихся военных предводителей» (Маннай-оол, 1970: 26). На них, как правило, были изображены животные (олени, маралы, лоси, кабаны, лошади и др.), «предметы вооружения и знаки (кинжалы, чеканы, луки), круглые диски, перекрещенные четырехугольники, пятиугольники неправильной формы, круги с точкой посередине, три линии, опоясывающие верхнюю часть стел подобно ожерелью из бус или гривне, а также пояса, высеченные на уровне поясницы» (там же: 24).

В контексте исследуемой темы оленные камни чрезвычайно информативны и представляют большой интерес для анализа трансформации религиозных представлений, отраженных в символах зооморфного стиля.

В частности, круги на вершине оленного камня (иногда интерпретируемые как глаз рыбы или зеркало) могли символизировать солнце и отражать существовавший солярный культ, в то время как изображения животных - отсылать к зооморфным культам и тотемистическим представлениям. К таковым можно отнести, например, выбитые на камне изображения оленей (единично стоящих, как на оленных камнях, найденных в Туве, или же несущихся галопом оленей с тяжелыми ветвистыми рогами, как в Монголии), лошадей, баранов (фото 1-2).

Можно также отметить у племен, сооружавших оленные камни, и культ предков, поскольку сами памятники, по сути, символизировали «умерших уюкских героев» (там же: 97). Весьма показательна в этом плане и сама форма оленных камней, на которых, как правило, выбивался «высеченный пояс, к которому привешены различные предметы вооружения (кинжалы, боевые топоры, чеканы, луки в налучьях) и целый ряд других вещей, присущих человеку, хотя никаких других черт человеческих фигур на них нет» (там же: 26).

Наличие линий-радиантов, исходящих от кургана в центре, а также особенности расположения оленных камней около херексуров позволяют предположить сосуществование и определенную синергию религиозных верований - культов Солнца, предков, определенных животных-тотемов -

\footnotetext{
${ }^{1}$ Кэрэксуры, херексуры (от монг. хиргис-хур - кыргызская могила) - древние каменные сооружения на Алтае, территории Тувы и Монголии, в Забайкалье. См.: Николаев Н. Н. Керексуры [Электронный ресурс] // Большая российская энциклопедия. URL: https://bigenc.ru/archeology/text/2061323 (дата обращения: 10.01.2021).
} 


\section{НОВЫЕ ИССЛЕДОВАНИЯ ТУВЫ}

www.nit.tuva.asia

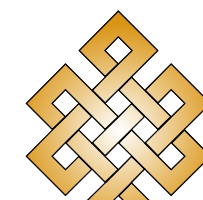

\section{THE NEW RESEARCH OF TUVA}

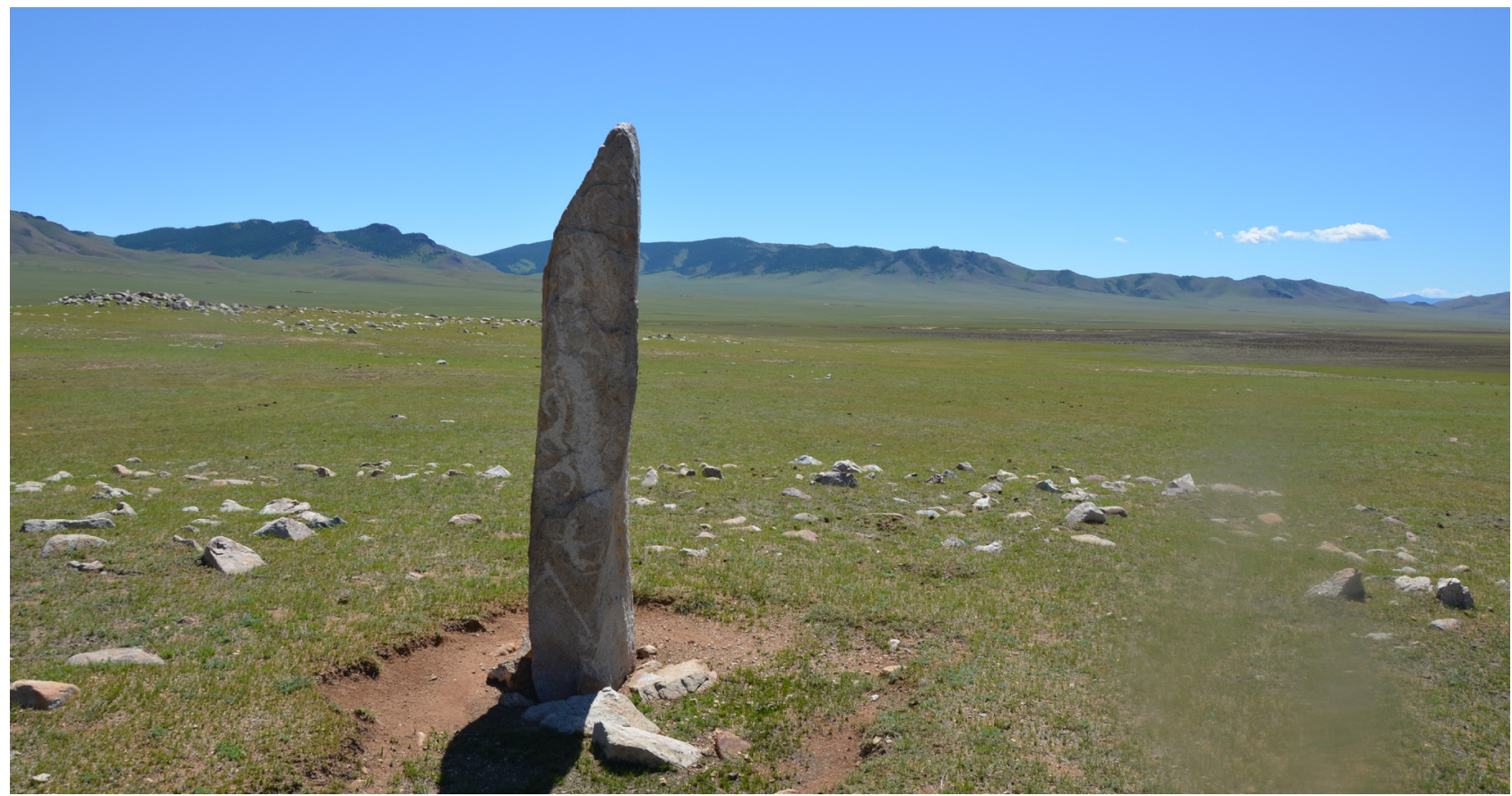

Фото 1. Оленный камень, Архангайский аймак, Монголия. Фото Н. Базылхана, 2018 г. Из личного архива Напиль Базылхана. Photo 1. A deerstone from Arkhangai aimag, Mongolia. Photo by N. Bazylkhan, 2018, from Napil Bazylkhan's personal collection.

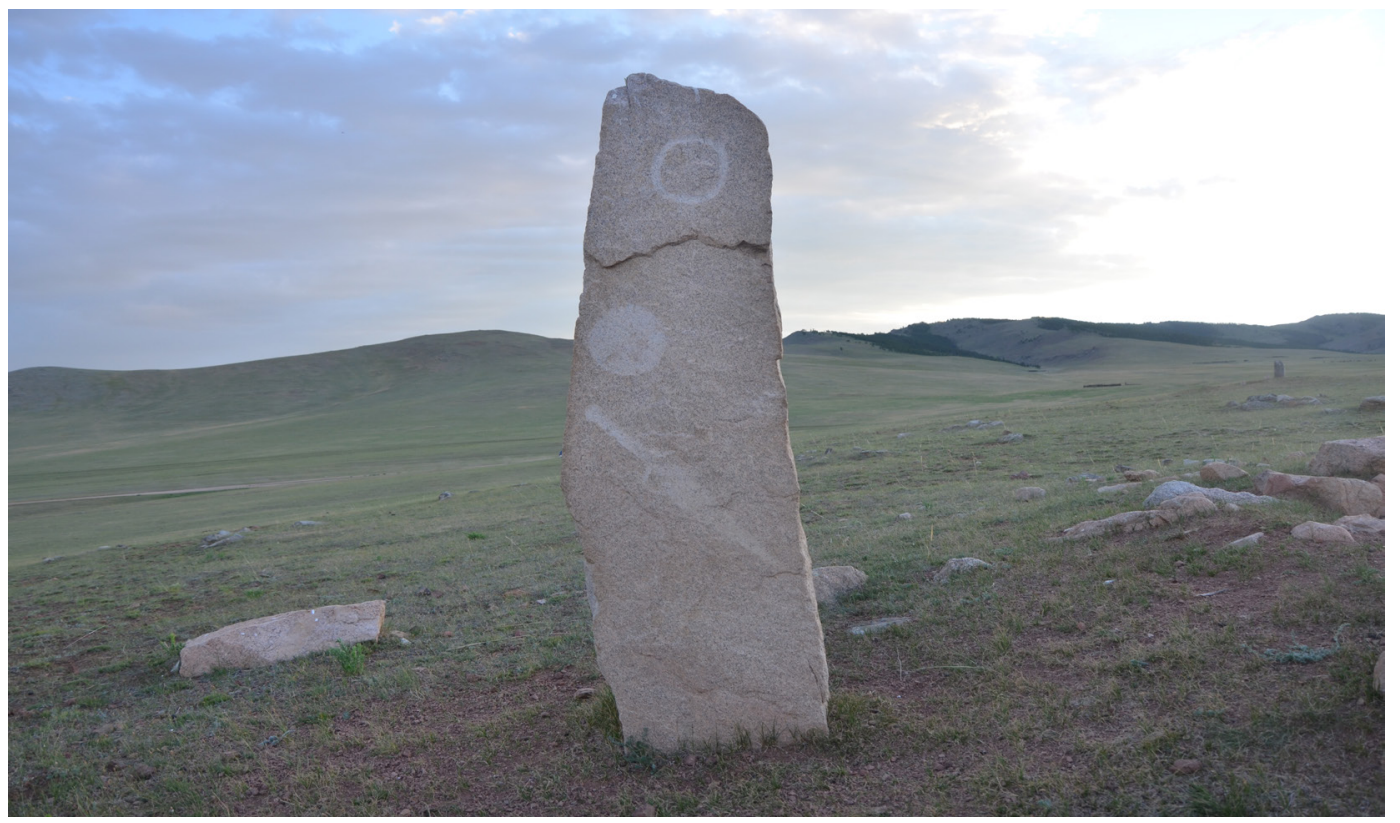

Фото 2. Оленный камень, Булганский аймак, Монголия. Фото Н. Базылхана, 20072.

Из личного архива Напиль Базылхана.

Photo 2. A deerstone from Bulgan aimag, Mongolia. Photo by N. Bazylkhan, 2007, from Napil Bazylkhan's personal collection.

в их органической взаимосвязи. Иными словами, культ предков естественным образом вписывался в религиозные представления, связанные с поклонением солнцу, что и получало отражение в общем композиционном устройстве данных сакральных сооружений. Что касается тотемических представлений, то они выражались в изображениях на оленных камнях определенных животныхтотемов, призванных как бы ограждать усопших и в потустороннем мире.

Таким образом, если исходить из того, что оленные камни устанавливались как дань тому или иному усопшему знатному человеку в рамках некоего единого в композиционном плане комплекса, 
то в данном качестве они могут считаться символическим проявлением сложившихся синкретических религиозных представлений, аккумулируя в себе, как минимум, солярные, тотемические верования, культ предков.

Вместе с тем оленные камни можно рассматривать также и как важный этап в дальнейшем развитии религиозных представлений и их последующей детализации в сторону будущего антропоморфного изображения и постепенного включения человека (хотя бы и в абстрактном виде) в систему религиозной символики.

В этом смысле очень интересна уникальная пара оленных камней, найденных в Баян-Улгийском аймаке Монголии (фото 3), один из которых выполнен в «классическом» стиле, без антропоморфных черт, с большим солярным кругом на вершине, выбитыми изображениями животных.

Другой же оленный камень, помимо того, что он сделан из камня совершенно иного - песочного цвета, более узкой ширины, выделяется включением антропоморфной детализации лица

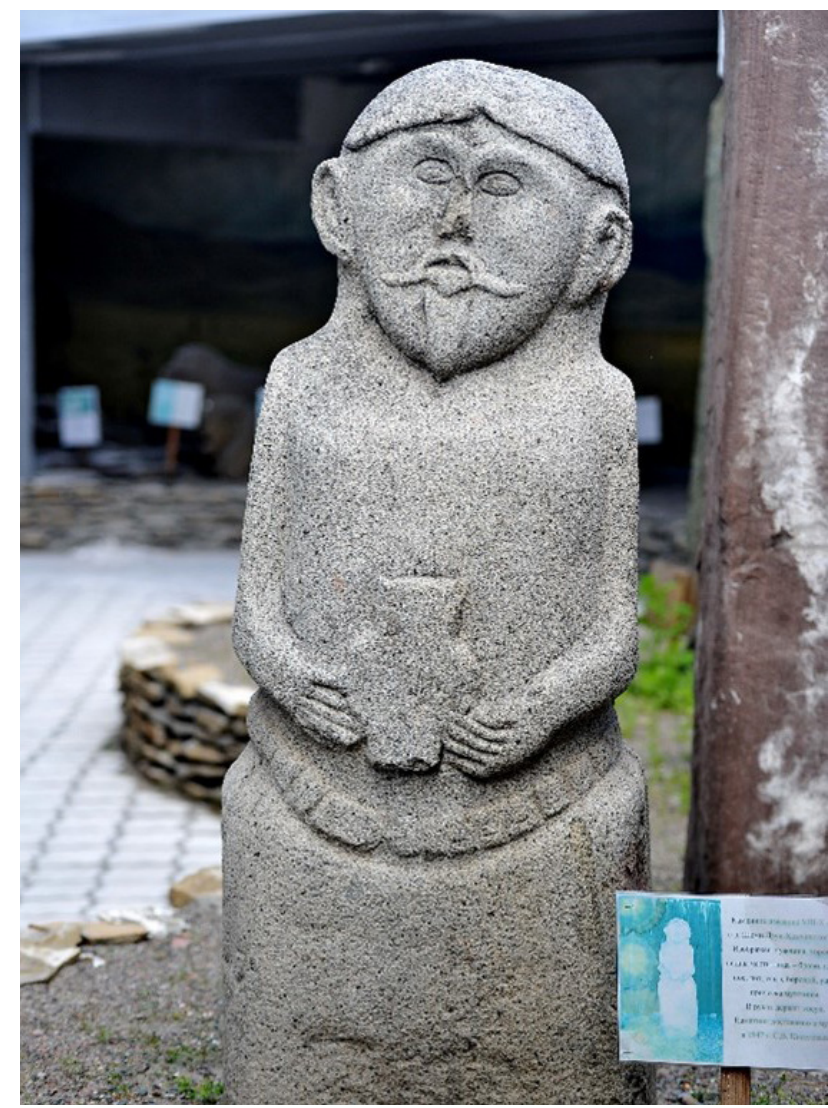

Фото 4. Изображение древнетюркского воина «Кижи Кожээ». VIII-Х вв. Камень. Фото Национального музея им. Алдан-Маадыр Республики Тыва.

Photo 4. Turkic warrior Kizhi Kozhee, 8-10th century CE.

Photo from the collection of the Aldan Maadyr National Museum of the Republic of Tuva.

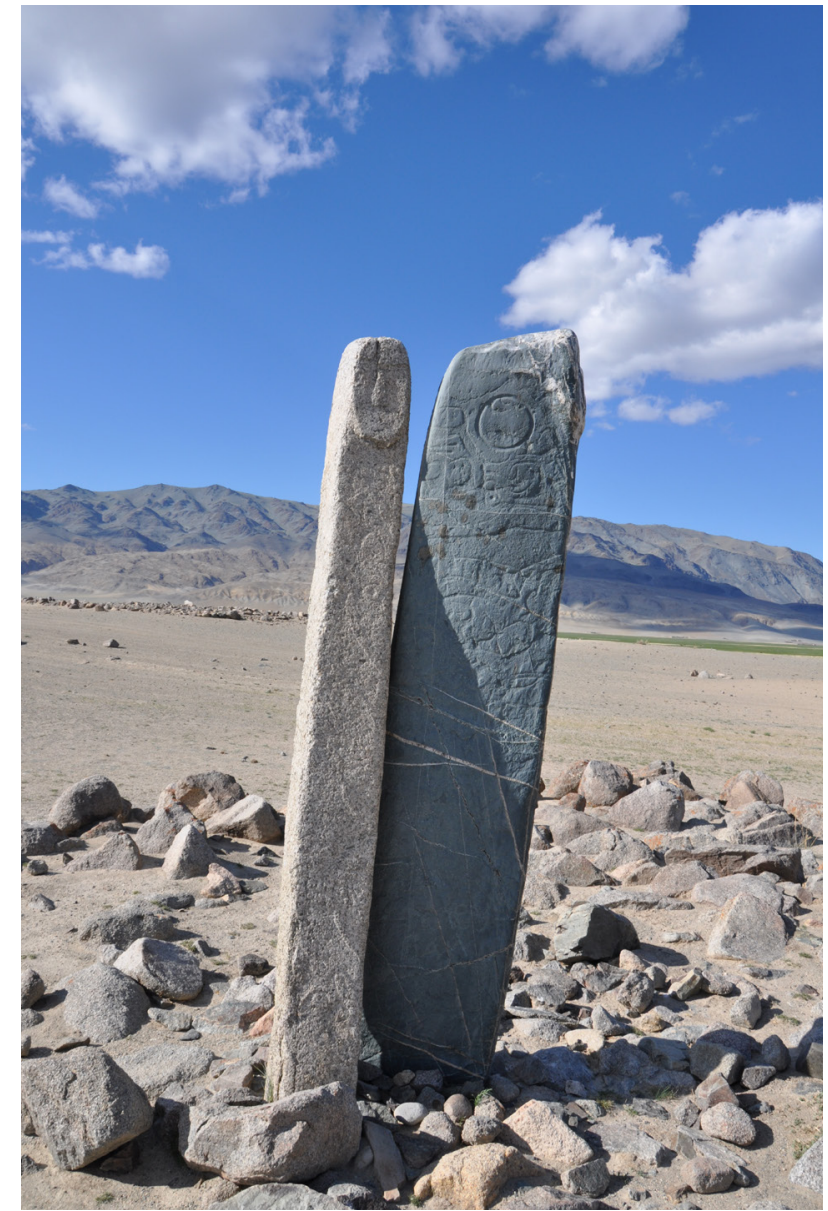

Фото 3. Пара оленных камней, Баян Улгийский аймак, Монголия. Фото Н. Базылхана, 2013 г. Из личного архива Напиль Базылхана. Photo 3. A couple of deerstones from Bayan-Ölgii aimag, Mongolia. Photo by N. Bazylkhan, 2013, from Napil Bazylkhan's personal collection.

на вершине камня. Можно предположить, что, возможно, он был сделан и приставлен позже, в период, когда постепенно стала отходить в прошлое каноническая общность и целостность, а своеобразный холизм стал уступать место более выраженной детализации изображений. Возможно, данный вид оленных камней мог являться своеобразным переходным этапом на пути к каменным антропоморфным изваяниям последующих периодов.

Поэтому можно предположить, что в последующие периоды дальнейшим шагом в сторону включения человека в религиозную символику стало аналогичное в смысловом плане изображение умерших знатных воинов или поверженных врагов в виде каменных изваяний, по-тувински кижи кожээ, или «каменный человек» (Грач, 1955: 422) с уже выписанными и стилистически структурированными элементами тела, головы и лица (фото 4). 
При этом аналогичное оленным камням изображение воинского вооружения на условном поясе это, как правило, выбитые на камне единичные кинжалы, ножи. Солярные знаки и изображения животных на каменных изваяниях уже исчезают, зато появляются чаши, кубки, которые держат в руках изображенные умершие, что передает сакральный смысл данного сюжета, связанный со священным напитком, поднесенным божествам, духам. В Центральной Азии данным священным напитком издревле являлся кумыс, который приносился в своеобразную жертву. Интересно отметить, что, например, среди якутов и в современное время отмечались обряды жертвоприношения, связанные с кумысом. По мнению исследователей, «все жертвоприношения божествам айыb бескровные - во время праздника жертвуют бело-молочным кумысным напитком. Поднимают вверх ритуальный большой сосуд чороон - айах, наполненный молочным напитком кумыс, для угощения Aйыb Танара, и всех его эманаций - небесных духов-божеств айыы ...» (Толстякова, 2019: 264). В случае с индоиранской традицией данную функцию выполнял аналогичный сакральный напиток бессмертия - известный на санскрите как сома и как хаома у древних иранцев.

Каменные изваяния можно считать дальнейшим развитием оленных камней, с уже выраженной антропоморфностью скульптур, привнесением новых элементов (чаши с сакральным напитком), отражавших почитание верховного божества Тенгри / Танэри / Танара. Отсутствие изображения солярных знаков и тотемных животных могло свидетельствовать о снижении значения данных верований. Вместе с тем продолжали оставаться значимыми культ предков, тенгрианско-шаманские представления. Показателен сам факт исключительно широкого распространения данных каменных изваяний в степной зоне Евразии, в частности, на территории современного Казахстана, Украины, известных под названиями балбал, «каменных баб», в первом тысячелетии нашей эры, как и ранее зооморфного стиля в предыдущем тысячелетии, который также охватывал собой значительный пояс Евразии от востока до Причерноморья. Все это может свидетельствовать о преемственности традиций и своеобразной эволюции оленных камней и зооморфного стиля в новые формы, сложившиеся в Евразии.

Таким образом, соединение смыслов, относящихся к древнейшим культам - солярному, тотемистическому, предков - на оленных камнях, которые, в свою очередь, также являлись частью более общей сакральной композиции курганов-херексуров солярного типа - все это позволяет говорить о преемственности религиозных воззрений и их синкретизме, или своеобразной инклюзии в рамках своеобразной религиозной семиосферы. Более ранние религиозные верования, такие как солярный культ, все еще продолжали включаться в общую систему религиозных представлений и получали свою символическую репрезентацию на данных сакральных памятниках. Показательно, что столь насыщенное в смысловом плане синкретическое содержание имело свое яркое выражение и в декоративно-прикладном и ювелирном искусстве, выполненном в зооморфном стиле.

Декоративно-прикладное, ювелирное искусство. Как известно, наиболее распространенными чертами, составляющими общие стилистические особенности зооморфного стиля, являются изображения животных и птиц (как реальных, так и фантастических), как правило, представленных парами, симметрично друг другу в зеркальном отражении, или же, наоборот, запечатленных в сценах терзания и борьбы, или же изображенных стоящими/сидящими/бегущими отдельно, попарно, в группах или «торжественно» следующими друг за другом, или же свернутыми по кругу так, что морда и хвост зверя соединены вместе, образуя своеобразное кольцо. В литературе, посвященной описанию особенностей данного стиля в найденных артефактах, отмечаются различные изображаемые животные, как правило, лошади, бараны, олени, волки, львы, тигры, лоси, быки, фантастические драконы, грифоны, изображения полулюдей-полуптиц с большими клювами и когтями, и др. (Руденко, 1953, 1962).

Данное стилистическое решение, ставшее своеобразной «визитной карточкой» зооморфного искусства, свидетельствует, в первую очередь, об исключительной роли культа животных как тотемов, защитников и охранителей родов. Ключевые животные-тотемы переданы древними мастерами разнообразно - как одиночные животные, как группа животных, идущих поодиночке, как парные изображения и как животные в схватке. Думается, что данная разная репрезентация не случайна, а напрямую связана также с различной ролью, которую играли в различных ситуациях одни и те же животные в жизни людей.

Концептуально можно выделить следующие основные виды изображений животных, выполненных: 1) в экспрессивном стиле; 2) с сакральной символикой. 


\section{1) Изображения животных в экспрессивном стиле}

К первому виду можно отнести изображения животных на определенных предметах (как правило, это нашивки, поясные пластины бляшки на одежде человека, воина, элементы конской сбруи, седел, вооружения), которые представлены в сценах «терзания», борьбы, то есть в экспрессивном стиле. В данном случае в функциональном плане предметы с изображениями «борющихся» животных могли иметь оберегающий и охранительный смысл, защищающий человека, всадника и его лошадь. Определенное животное-тотем представало в виде оберега целого рода, а «атакующий» сюжет изображенного животного в схватке с другим мог нести также и более широкий посыл - доминирование одного рода (племени, союза племен) над другим (другими).

В подобном ключе можно рассматривать многие находки, в том числе ярко представленные в Сибирской коллекции ${ }^{1}$, где в сценах борющихся животных представлены волки, ти

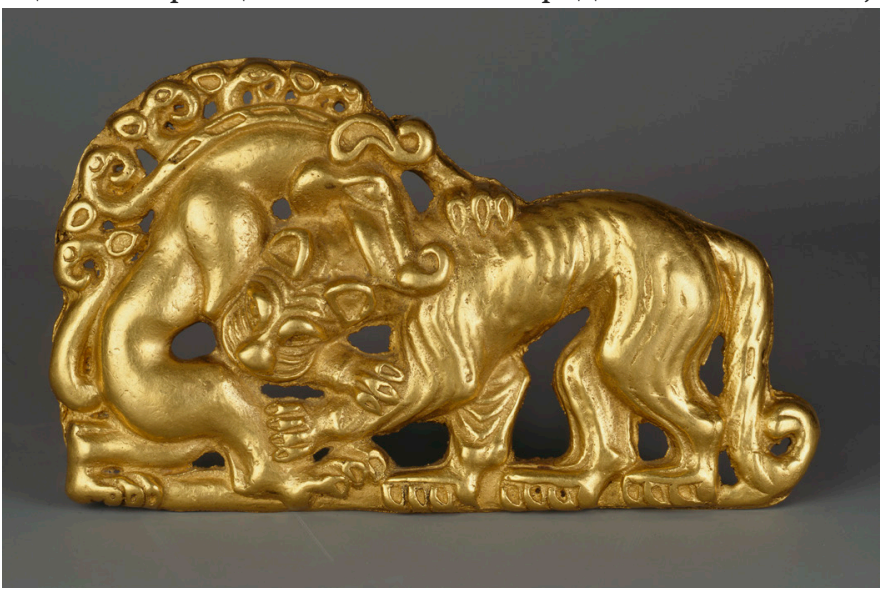

Фото 6. Поясная бляшка (схватка тигра с фантастическим волком). VI в. до н. э. Золото. Си.1727-1-11.

Фото А. М. Кокшарова, В. С. Теребенина, Л. Г. Хейфеца; Государственного Эрмитажа, г. Санкт-Петербург.

Photo 6. A belt plate (the fight between a tiger and a snake).

6th century BCE. Gold. Si.1727-1-11. Photo by A. M. Koksharov,

V. S. Terebenin, L. G. Kheifets, State Hermitage Museum, St. Petersburg.

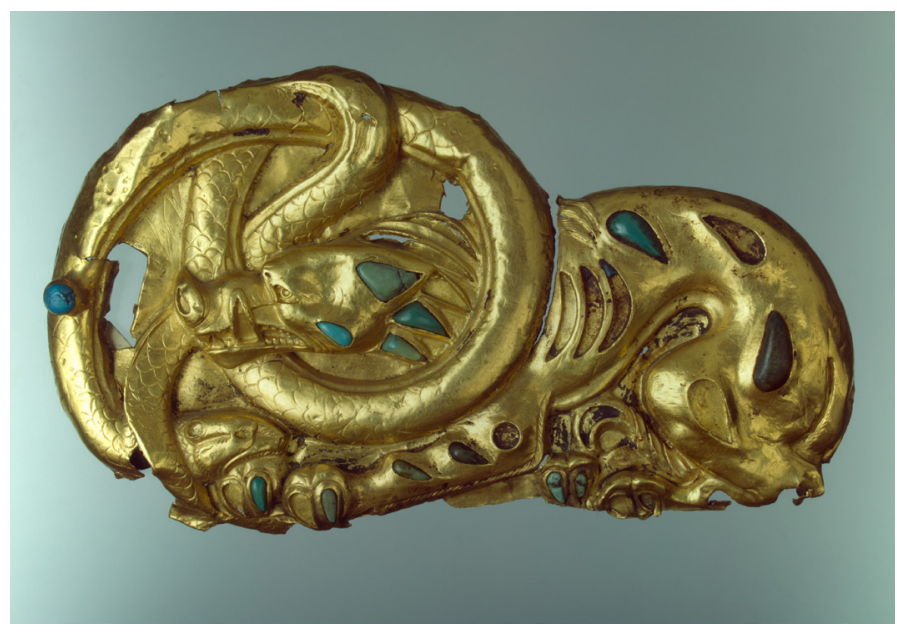

Фото 5. Поясная бляшка (схватка волка со змеей). IV-III вв. до н. э. Золото. Си.1727-1/150.

Фото А. М. Кокшарова, В. С. Теребенина, Л. Г. Хейфеца;

Государственного Эрмитажа, г. Санкт-Петербург.

Photo 5. A belt plate (the fight between a wolf and a snake). 4th-3rd century BCE. Gold. Si.1727-1/150. Photo by A. M. Koksharov, V. S. Terebenin, L. G. Kheifets; State Hermitage Museum, St. Petersburg.

тигры, пантеры, быки, некоторые из которых изображены в фантастическом, мифическом, синкретическом виде. К таковым можно отнести, в частности, изображения сцен схватки волка со змеей (фото 5) или тигра с фантастическим волком (фото 6) на поясных пластинах из Сибирской коллекции, хранящейся в Государственном Эрмитаже (Россия).

Данные изображения «в схватке» отражают животных, функционально выполнявших функцию тотемного животного защитника рода, что в религиозном плане свидетельствует о распространении тотемизма и тотемных представлений. Думается, что подобная практическая, прикладная направленность данного вида изображений может свидетельствовать об определенных процессах, происходивших в древних обществах середины первого тысячелетия до нашей эры.

Это процессы взаимодействия/противостояния племен, их миграции (что неудивительно, принимая во внимание широкое распространение звериного стиля на евразийском континенте), в ходе которых во взаимодействие вступали самые разные группы и союзы племен, тотемными покровителями которых являлись разные звери. Поэтому вполне логично допустить, что сцены «терзания» - это не просто тотемный знак, но также и символ доминирования одной социальной группы над другой. Одновременно, сцены животных «в схватке» могли иметь и более заземленный смысл удачной охоты, когда ловля зверя практически голыми руками, или облавная

${ }^{1}$ Наиболее изученная Сибирская коллекция Петра I была найдена еще в начале XVIII века, но детально каталогизирована и описана лишь в середине XX столетия С. Е. Руденко (Руденко, 1962). 
охота (Кореняко, 2002: 152-158) также вынуждали охотника представлять себя в виде того или иного тотемного животного, побеждающего противостоящего ему зверя, который представал уже в виде

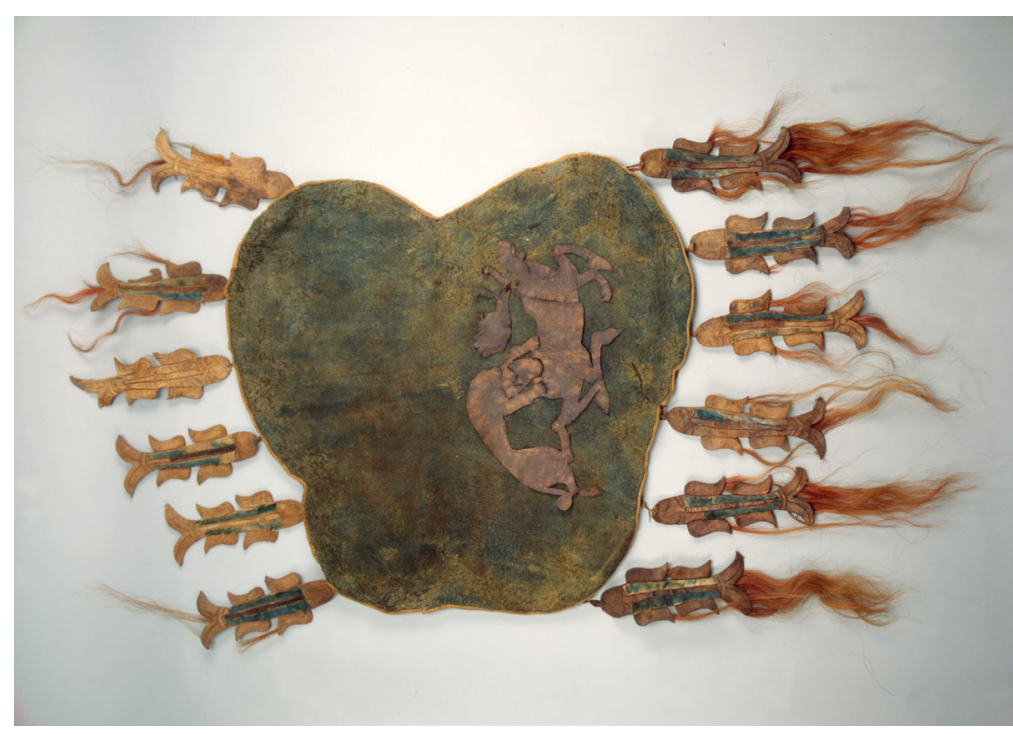

Фото 7. Покрытие на седло с аппликацией. Рубеж IV-III вв. до н. э. Шерсть, войлок, кожа, конский волос. Длина 53 см; ширина 48 см. 1295-248.

Фото А. М. Кокшарова, В. С. Теребенина, Л. Г. Хейфеца; Государственного Эрмитажа, г. Санкт-Петербург.

Photo 7. An applique saddle cover. Turn of the 3rs century BCE. Wool, felted cloth, leather, horse hair. 53 x 48 centimeters. 1295-248. Photo by A. M. Koksharov, V. S. Terebenin, L. G. Kheifets; State Hermitage Museum, St. Petersburg. жертвы. В качестве своеобразного оберега и защиты использование таких пластин нашивок на одежде и поясе человека, воина показывает также и использование элементов магии и магических верований. Все это получало отражение в символической репрезентации.

Исключительно показательным примером в данном контексте является чехол седла, сделанный из войлока, кожи, меха и конского волоса, который был найден в Первом Пазырыкском кургане (фото 7).

На хорошо сохранившемся седельном чехле центральным элементом композиции на правой стороне седла является аппликация из кожи, изображающая нападающего на оленя тигра и терзающего его. Интересным в этом артефакте является декорация данного седла свисающими изображениями 12 рыб, сделанных из кожи с приклеенными конскими волосами и покрытых голубой краской, местами сохранившейся. Такой же голубой краской был покрыт и сам чехол.

Представленный артефакт символически насыщен и репрезентативен. Символическое значение сцены «терзания», как было отмечено выше, может состоять в доминировании одного тотемного животного, а вместе с ним, и определенной социальной группы (племени) над другим; или же в благопожелательном символе удачной битвы с врагом или охоты на животных. Что касается изображения рыб, то они отсылают нас к древним представлениям, связанным с почитанием рыб в качестве тотемов, что хорошо представлено в том числе на «рыбообразных» оленных камнях, найденных в Туве, Монголии и Забайкалье (Маннай-оол, 1970: 28).

Классик тувиноведения М. Маннай-оол очень хорошо показал данную связь, отметив следующее:

«По данным этнографии, образ рыбы занимает важное место в культуре и мифологии народов Южной и Восточной Сибири. По сказаниям бурят, тотемными предками эхиритов-булагатов считались темно-серый бык - буха-нойон и рыба налим, обитавшая в оз. Байкал... Известно, что среди тувинцев имелась родовая группа (сеок) под названием “балыкчы”, т. е. рыбак. Г. Н. Потанин, посетивший Туву в 80-х годах XIX в. писал, что тувинцы “над костью балыкчы смеются, что она происходит от рыбы”... Б. К. Шишкин, побывавший в Туве в начале XX в., сообщает, что тувинцы “охотно едят всякую рыбу за исключением налима, о котором существует предание, что это утонувшая женщина” .... Деревянные резные скульптурные изображения рыб служили деталями шаманских идолов у тувинцев... Образ рыбы наряду с оленями, горными козлами... и другими животными фигурировал в изобразительном искусстве и в атрибутах верований племен евразийских степей в 1 тысячелетии до н. э. Вероятно, рыбообразность некоторых оленных камней связана с культово-магическими представлениями древних людей» (там же: 29).

Тотемические представления людей, оставивших после себя замечательные памятники и предметы искусства, относимые исследователями к зооморфному стилю, исключительно ярко и выразительно показывают данные тотемы через их символическую репрезентацию. При этом обнаруживается наличие не одного, а сразу нескольких тотемов. Как видно на примере чехольного седла, наряду с «атакующими» животными, одновременно ими являются также и рыбы. 
Кроме того, можно отметить и наличие религиозных представлений, обычно ассоциируемых с шаманизмом и проведением ритуалов, связанных с камланием шаманов, очищением, защитой пространства, в которых используется конский волос в качестве важного атрибута. Например, в якутской традиции это белый сакральный, чистый конский волос, который применяется для проведения обряда алгыс (благословение) и арчы (очищение), и как образ сакрального пути, а также моста, связующего разные миры (Толстякова, 2019: 263, 265).

Вставки-аппликации из рыжего конского волоса на изображениях подвесок в виде рыб на седельном чехле из Первого Пазырыкского кургана могут свидетельствовать поэтому и о сакральном отношении как к лошади в целом, так и к лошадям определенной масти, в частности. Например, наряду с белой, лошадь рыжей масти также была сакральной. Как считалось, такая лошадь являлась олицетворением солнца, что показывают находки захоронений лошади рыжей масти с маской и рогами из Берельского кургана в Восточном Казахстане. Поэтому в качестве мощного оберега могло считаться использование конских волос именно сакральной лошади, то есть рыжей масти.

Число подвесок в виде рыб с аппликациями из конского волоса рыжего цвета - двенадцать, что не случайно, а могло быть связано с представлениями о циклическом, повторяющемся времени как круговороте природы. Наконец, символика раскраски рыб, как и всего седла синего или голубого цвета - также показывает значение культа Неба и верховного божества, позднее известного в древнетюркской мифологии как Тенгри / Танэри / Танара.

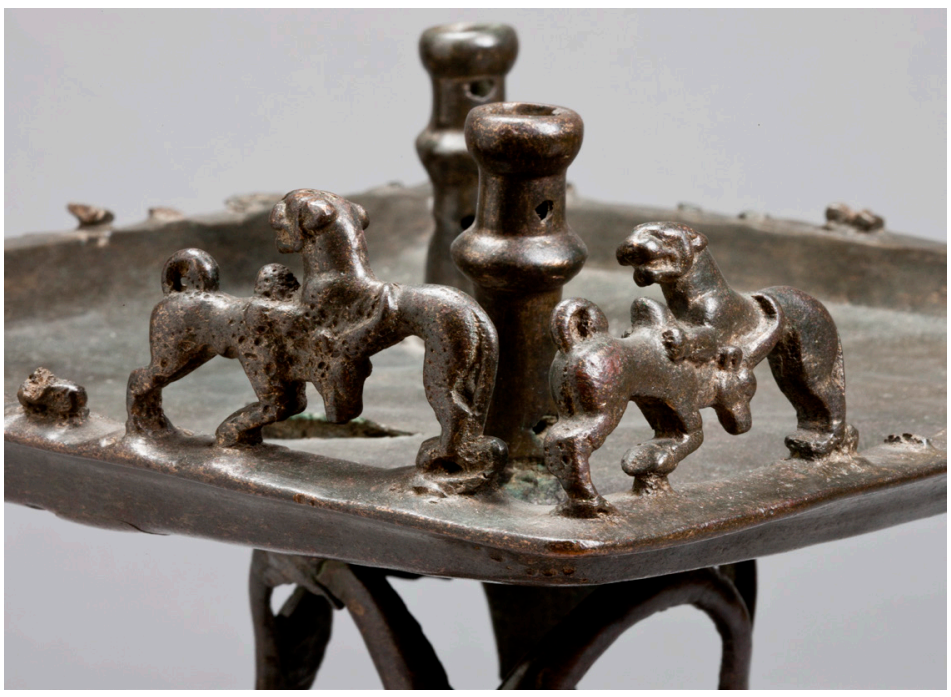

Фото 9. Курильница (деталь), Тянь-Шань. V-III вв. до н. э. Бронза. 24,8х24х28 см. СА-3187. Фото А. М. Кокшарова, В. С. Теребенина, Л. Г. Хейфеца; Государственного Эрмитажа, г. Санкт-Петербург. Photo 9. An incense burner (a fragment), 5th-3th $\mathrm{c}$. BCE. Bronze, $24.8 \times 24 \times 28 \mathrm{~cm}$. CA-3187.

Photo by A. M. Koksharov, V. S. Terebenin, L. G. Kheifets, State Hermitage Museum, St. Petersburg.

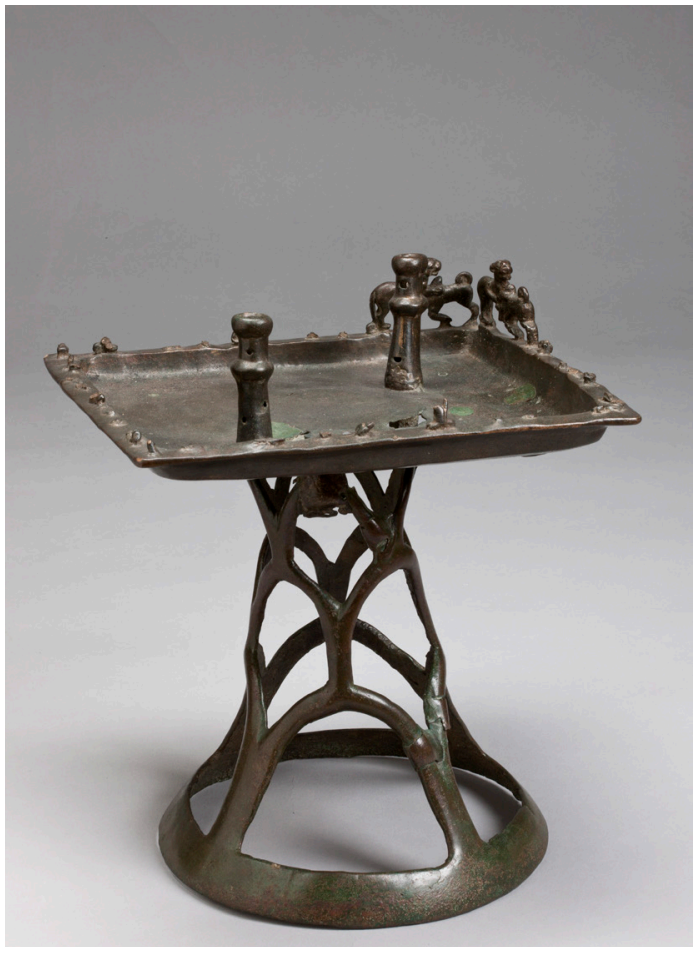

Фото 8. Курильница, Тянь-Шань. V-III вв. до н. э. Бронза 24,8x24x28 см. СА-3187.

Фото А. М. Кокшарова, В. С. Теребенина, Л. Г. Хейфеца; Государственного Эрмитажа, г. Санкт-Петербург. Photo 8. An incense burner, 5th-3th c. BCE. Bronze, $24.8 \times 24 \times 28 \mathrm{~cm}$. CA-3187.

Photo by A. M. Koksharov, V. S. Terebenin, L. G. Kheifets;

State Hermitage Museum, St. Petersburg.

Исходя из изложенного выше, можно отметить, что сакральность пространства и времени была связана с почитанием тотемных животных и рыб, с сакрализацией лошади белой и рыжей мастей как олицетворением солнца, с шаманскими и тенгрианскими представлениями.

Изображения сцен схваток и терзания с их оберегающими функциями хорошо представлены на бронзовых курильницах из Семиречья, хранящихся в коллекции Государственного Эрмитажа.

На бронзовой курильнице прямоугольной формы в центре расположены две вертикальные подставки для благовоний, вдоль периметра курильницы изображены пары животных в схватке (буйвол и пантера), изначальное количество которых составляло 12 пар, из которых уцелело только 2 пары (фото 8-9). 

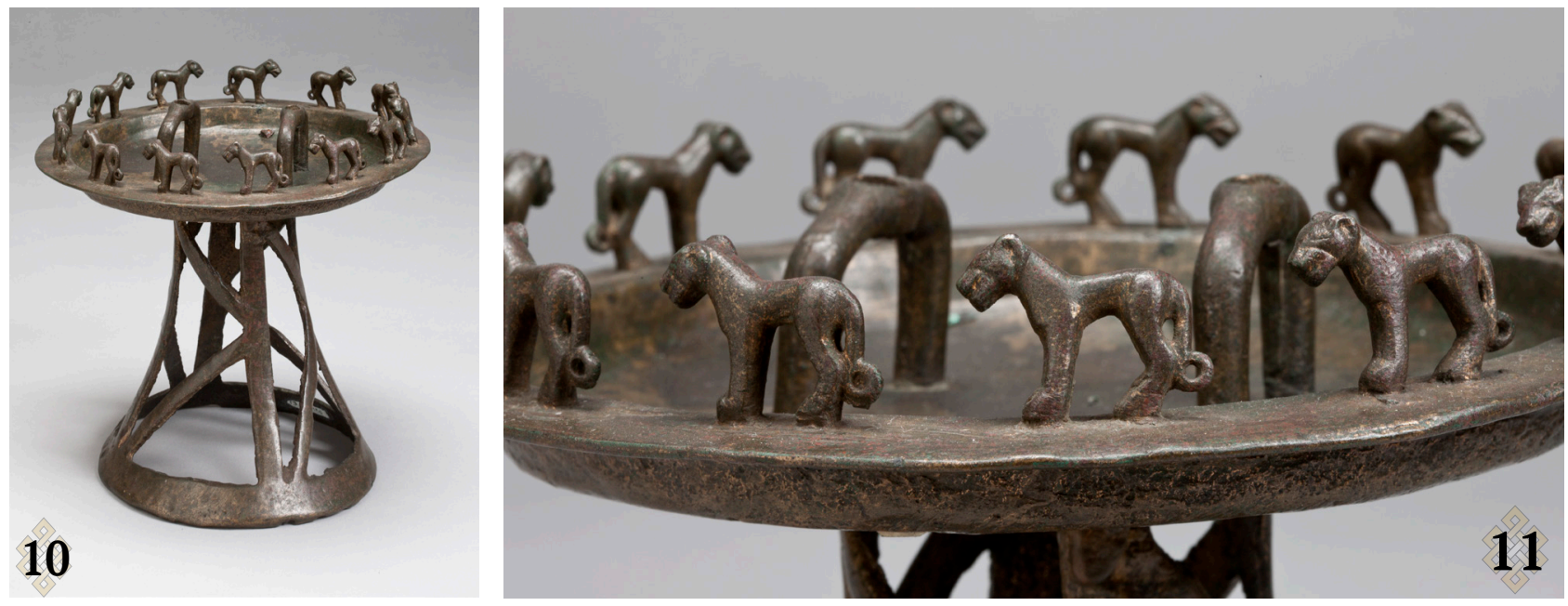

Фото 10-11. Курильница (10) и ее деталь (11), Тянь-Шань. V-III вв. до н. э. Бронза. Высота: 16; D-21 см. CA-3186. Фото А. М. Кокшарова, В. С. Теребенина, Л. Г. Хейфеца; Государственного Эрмитажа, г. Санкт-Петербург.

Photo 10-11. An incense burner (10) and fragment (11), 5th-3th c. BCE. Bronze, $16 \mathrm{~cm}$ high and 11 in diameter. CA-3186. Photo by A. M. Koksharov, V. S. Terebenin, L. G. Kheifets; State Hermitage Museum, St. Petersburg.

Ритуальный характер данного предмета, усиленный подставками для благовоний, подчеркивает большую роль, которую играли для древних людей акты очищения пространства. Относительно небольшой размер данной, а также другой (фото 10-11) курильницы позволяет предположить, что они устанавливались в помещениях, возможно, в сакральных местах для проведения религиозных актов, отражавших просьбы об умилостивлении или принятии благодарности.

Характерно композиционное построение курильниц, прямоугольная или круглая формы которых покоятся на своеобразных четвероножниках, соединенных в основании кругом. Визуально данная композиция напоминает древо - arbor mundi - или мировое дерево, традиционный символ связи трех миров воедино. Собственно подставки курильниц образуют крону, верхнюю часть древа, или так называемый верхний сакральный мир. При этом животные, обрамляющие периметр, изображенные «в схватке» или торжественно шествующие друг за другом, словно обходя и защищая сделанные

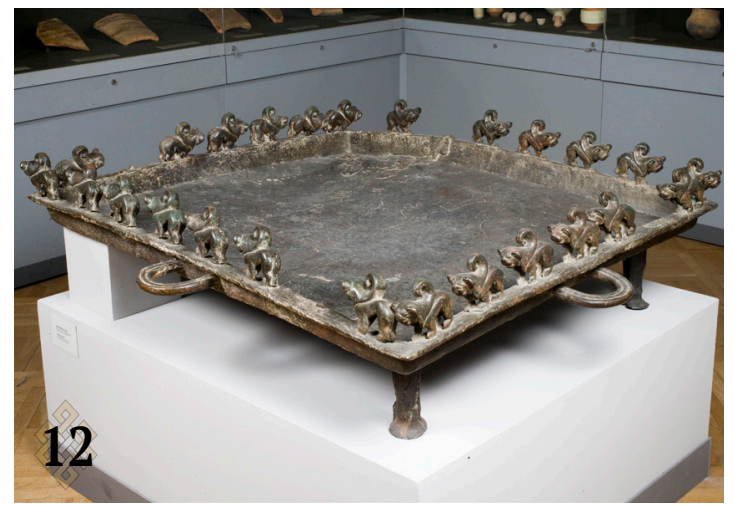

Фото 12-13. Жертвенник на четырех ножках (12) и его деталь (13). Семиречье, Казахстан. V-III вв. до н. э. Бронза. Высота: 34 см; 1,25х1,22 см; длина: 10 см (ручки); длина: 13 см (зверя). СА-13760. Фото А. М. Кокшарова, В. С. Теребенина, Л. Г. Хейфеца; Государственного Эрмитажа, г. Санкт-Петербург. Photo 12-13. A sacrificial altar on four stands (12) and fragment (13), Semirechye, Kazakhstan, 5th-3th c. BCE. Bronze. $34 \mathrm{~cm}$ hign, $1.25 \times 1.22 \mathrm{~cm}$, handles $10 \mathrm{~cm}$ long, animal length $13 \mathrm{~cm}$. CA-13760.

Photo by A. M. Koksharov, V. S. Terebenin, L. G. Kheifets, State Hermitage Museum, St. Petersburg.

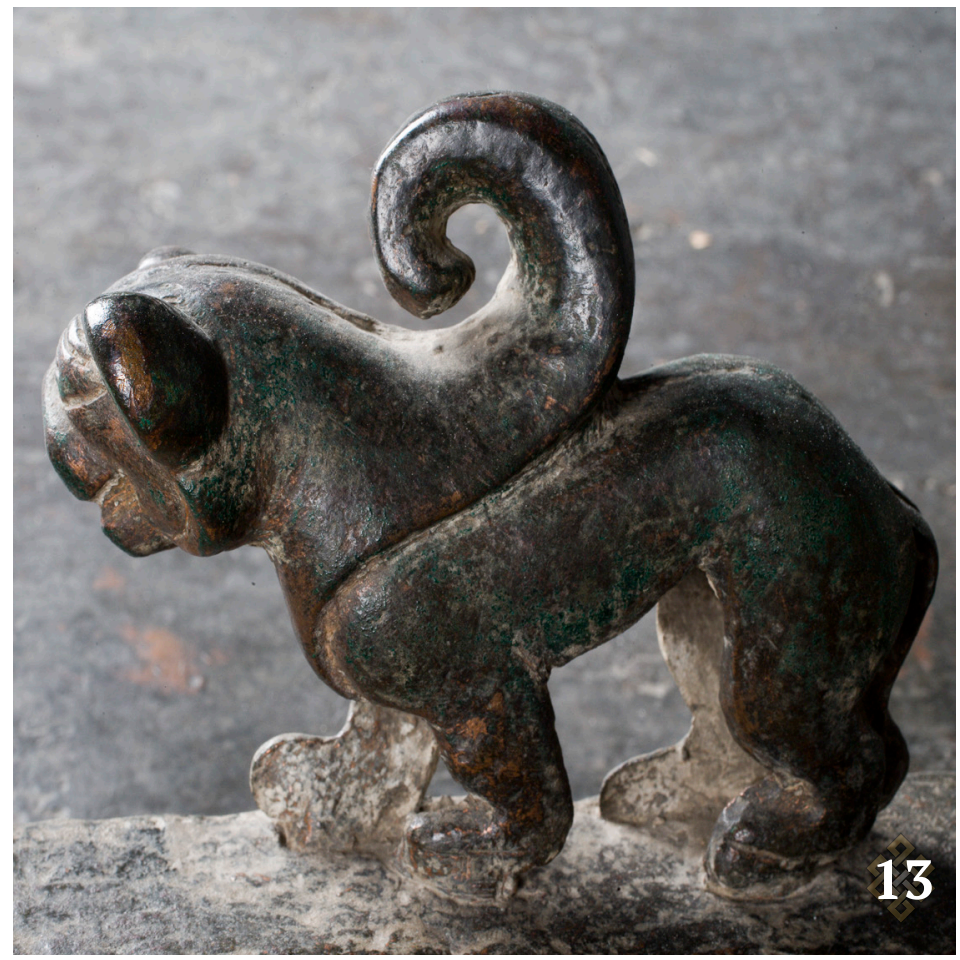


приношения божествам, духам, играют важную оберегающую и защищающую функцию в ходе исполнения ритуальных актов очищения определенного сакрального пространства.

Другой важный артефакт - большой ритуальный жертвенник, также найденный в Семиречье, являет собой пример того, что в качестве жертвоприношений могли использоваться не только символические подношения в виде даров природы, но также и возможные жертвоприношения животных (фото 12-13).

Об этом могут свидетельствовать размеры жертвенника - он достаточно большой, чтобы вместить в себя животное (возможно, домашнее), и имеет небольшую высоту. Его четыре ножки невысоки, «приземисты», выполнены в виде лап животных (льва?), что еще раз показывает важность иконографии животных и элементов их тел в исполнении разных предметов. Большой жертвенник имеет характерные ручки-захваты в виде полуколец с каждой стороны, что свидетельствует о том, что его могли переносить с собой.

Зооморфные сюжеты составляют центральную часть композиции и на военном снаряжении - кинжале из железа, покрытого золотом, найденном в кургане Аржан в Туве (фото 14).

Характерное парное симметричное расположение тигров на верхней и нижней частях рукоятки кинжала функционально отделяют ее от лезвия. В символическом плане устрашающие позы тигров с открытыми пастями и в полукольце призваны защитить его владельца (правителя) и одновременно устрашить врага. Тотемные и магические представления здесь, как и на других предметах, не вызывают сомнений. Данный и подобный ему кинжалы из собрания Национального музея Республики Тыва, найденные в кургане Аржан-2 возле скелета «царицы», представляет большой интерес, поскольку на клинке кинжала также четко представлены изображения солярных символов в виде сферических кругов, полукругов, завитков (фото 15).

В целом наличие солярных символов в изображениях, выполненных в зооморфном

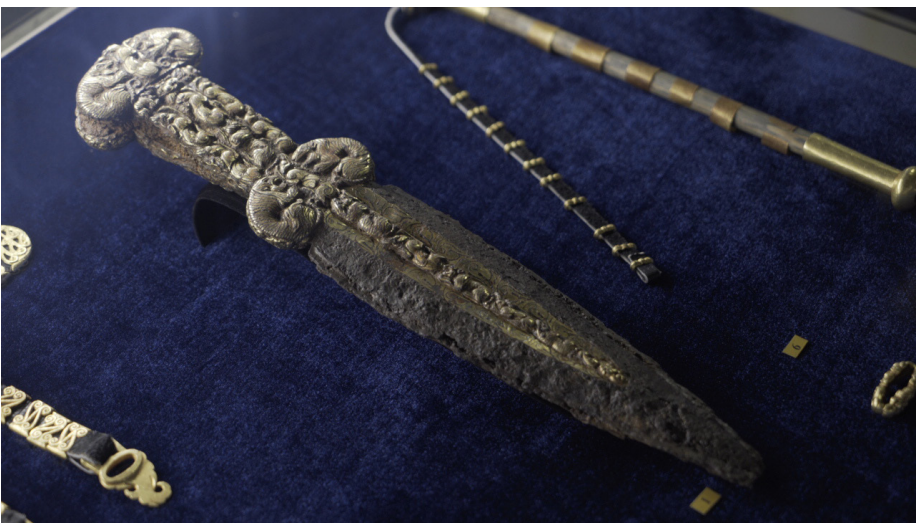

Фото 14. Кинжал, курган Аржан-2, Тыва. VII вв. до н. э. Железо, золото. Фото Тревора Уоллеса; Национального музея им. Алдан-Маадыр Республики Тыва.

Photo 14. A dagger, kurgan Arzhan II, Tuva. 7th c. BCE. Iron and gold. Photo by Trevor Wallace, Aldan Maadyr National Museum of the Republic of Tuva.

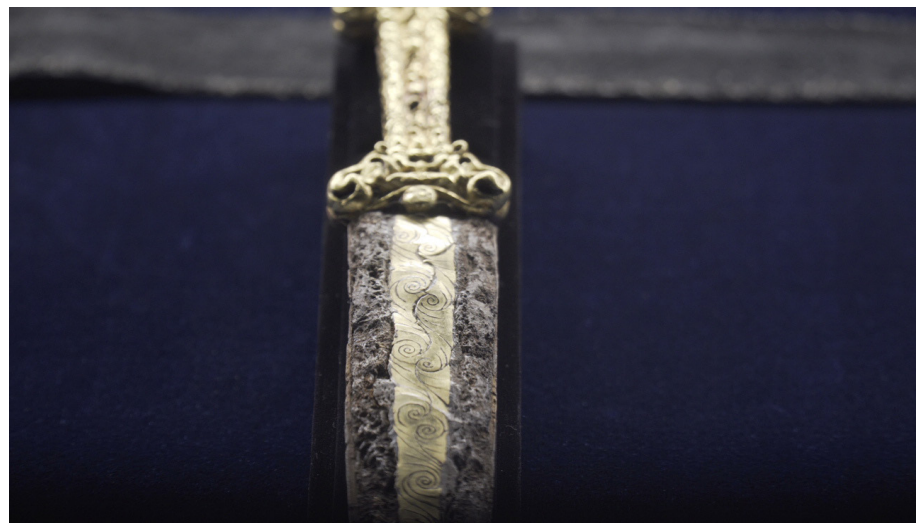

Фото 15. Кинжал, курган Аржан-2, Тыва. VII вв. до н. э. Железо, золото. Фото Тревора Уоллеса;

Национального музея им. Алдан-Маадыр Республики Тыва. Photo 15. A dagger, kurgan Arzhan II, Tuva. 7th c. BCE. Iron and gold.

Photo by Trevor Wallace; Aldan Maadyr National Museum of the Republic of Tuva. стиле, можно обнаружить на многих артефактах, материалах захоронений первого тысячелетия до нашей эры. Об этом будет изложено ниже.

(2) Сакральная символика в изображениях животных

Наряду с изображениями сцен схваток и «терзания», можно отметить и второй тип изображений животных, выполненных в зооморфном стиле. Он связан с единичными или парными животными лежащими, стоящими, идущими или галопирующими, иногда как бы парящими в полете. Животные, как правило изображены в своих естественных позах, в состоянии покоя, гармонии, или же, в необычной круговой манере, при которой морда и хвост зверя соединены между собой, а сами они как бы «вписаны» в круг. Как правило, такие изображения присутствовали на одежде, элементах конского снаряжения, особенно на конской сбруе, упряжи, а также на жертвенниках (см. выше). 


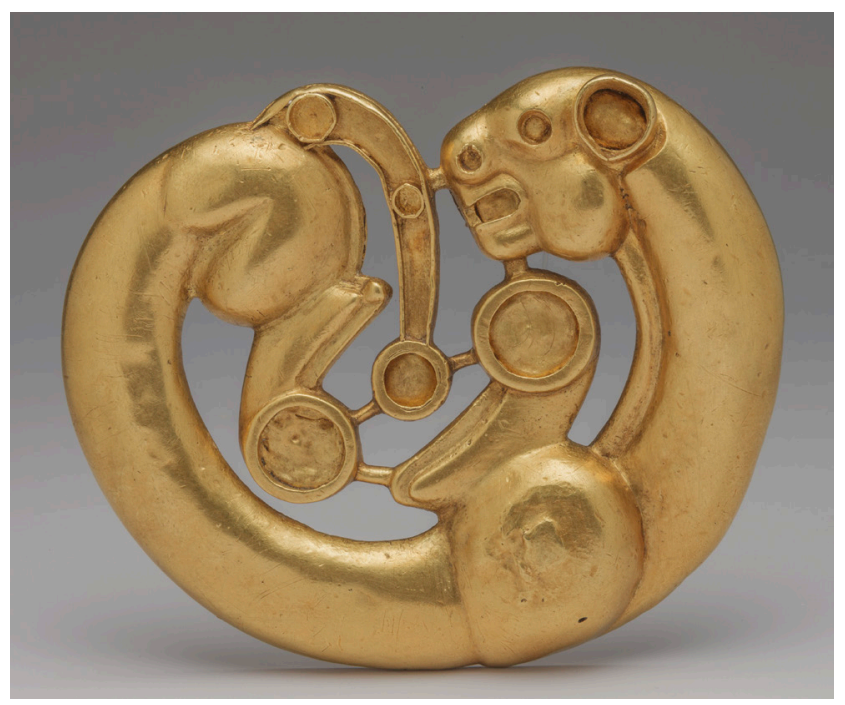

Фото 16. Зооморфная пектораль. VII-VI до н. э. Золото. Си.1727-1/88.

Фото А. М. Кокшарова, В. С. Теребенина, Л. Г. Хейфеца;

Государственного Эрмитажа, г. Санкт-Петербург.

Photo 16. A zoomorphic pectoral. 7th-6th c. BCE.

Gold. Si.1727-1/88 Photo by A. M. Koksharov, V. S. Terebenin, L. G. Kheifets,

State Hermitage Museum, St. Petersburg.

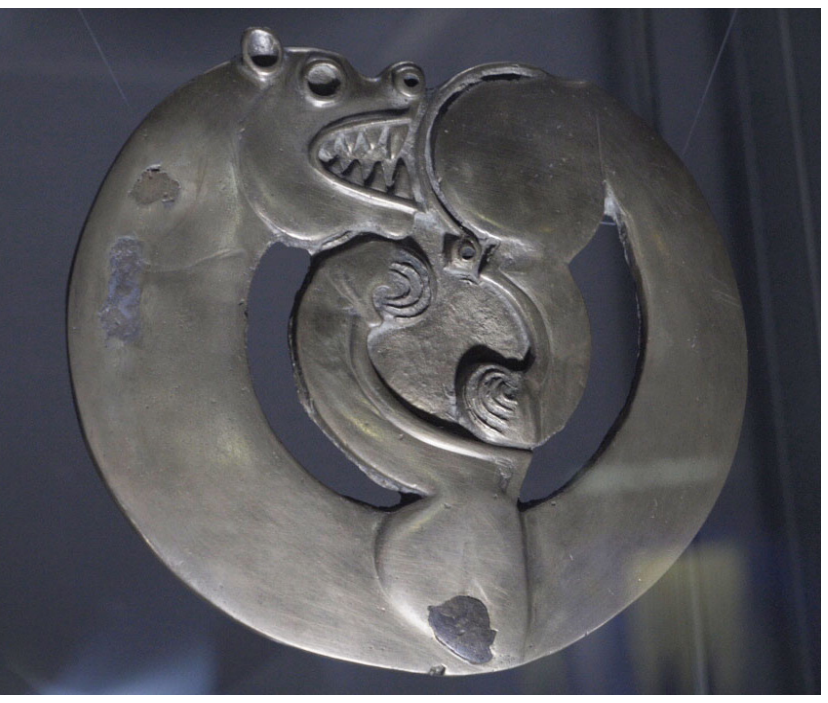

Фото 17. Конская нагрудная бляха в виде свернувшейся пантеры, курган Аржан-1, Тыва. IX-VII вв. до н. э. Бронза. Фото Тревора Уоллеса; Национального музея им. Алдан-Маадыр Республики Тыва.

Photo 17. A horse chestplate shaped as a coiled panther, kurgan Arzhan I, Tuva. 9th-7th c. BCE. Bronze.

Photo by Trevor Wallace, Aldan Maadyr National Museum of the Republic of Tuva.

Данный тип изображений животных носит ярко выраженную сакральную, оберегающую и защитную символику, являясь, по сути, оберегами и защитными талисманами, напрямую или косвенно отсылающую к солярным культам. О большой роли солярного культа для людей древности свидетельствуют разнообразные знаковые, смысловые и символические репрезентации - как непосредственно самого солнца в виде солярных кругов, круглых, полукруглых изгибающихся линий, так и круглых форм, в которые «вписывались» изображения животных.

К подобного рода изображениям можно отнести зооморфные бляшки, конские нагрудные украшения, сделанные в виде круга, в который исключительно изысканно и гармонично вписаны фигуры свернувшегося в клубок зверя - пантеры (фото 16-17).

По аналогии с зародышем морда зверя соприкасается с собственным хвостом, а согнутые лапы и хвост соединены между собой перемычками, что придает целостность, наполненность и гармонию композиции, а также создает впечатление сдерживаемой экспрессии, готовой развернуться и вылиться вовне, как только наступит для этого подходящий момент. Бляшка в зооморфном стиле, найденная в кургане Аржан и представленная в Национальном музее Республики Тыва, в концептуальном плане аналогична золотой бляшке из Сибирской коллекции, находящейся в собрании Государственного Эрмитажа. Обе они бесспорно репрезентируют солнце в его изначальной форме круга. Необходимо отметить, что изделия сакского/скифского стиля, особенно ранних периодов символично подчеркивают поклонение данному светилу. Как правило, некоторые их них, в частности, относящиеся к майэмирской культуре, выполнены из золота - драгоценного металла, символизирующего солнце по аналогии с цветом, с использованием круглых, полукруглых форм.

Множественные закругленные линии-полукольца, полукруги исключительно щедро представлены в артефактах зооморфного стиля. Изображения животных, даже если они не вписаны в круг, а изображены в натуральном виде, все равно не свободны от данного проявления солярного культа. Показательны в этом плане изображения животных на большом бронзовом жертвеннике (фото 12), исполненные в торжественно величавом виде. Мифические крылатые хищники, напоминающие львов, неспешно торжественно обходят по кругу, словно показывая величие происходящего акта жертвоприношения и защищая его от воздействий извне. При этом сами животные изображены древними мастерами с большими закругленными вверх полукольцами-завитками (фото 13), что, безусловно, отражает репрезентацию солнца. Использование данных деталей как своеобразных рудиментов прошлого, для 
отражения характера незримого присутствия Солнца и для поклонения этому небесному светилу, здесь представлено в органическом виде, соединяясь с изображением животных, которые могут олицетворяться с данным светилом.

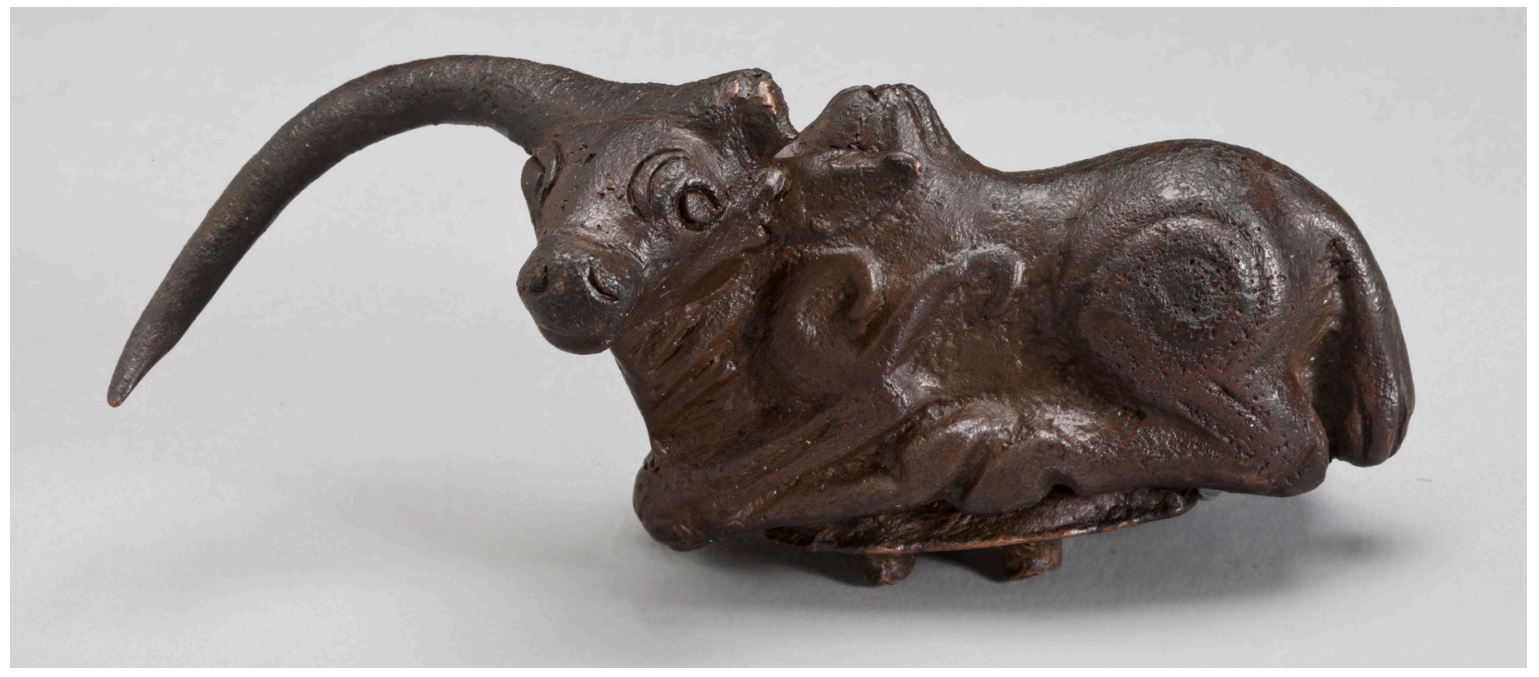

Фото 18. Фигурка быка-яка, Семиречье, Туркестан. V-III вв до н. э. Бронза. 4х2,8х5 см СА-3185 Фото А. М. Кокшарова, В. С. Теребенина, Л. Г. Хейфеца; Государственного Эрмитажа, г. Санкт-Петербург. Photo 18. A yak figurine, Semirechye, Turkestan, 5 th-3rd c. BCE. Bronze. $4.2 \times 8 \times 5 \mathrm{~cm}$.

CA-3185. Photo by A. M. Koksharov, V. S. Terebenin, L. G. Kheifets, State Hermitage Museum, St. Petersburg.

Показательным примером отображения сакральности некоторых животных, так называемых «животных-солнце», можно считать изображение лежащего бронзового быка, найденного в Семиречье (V-III вв. до н. э.), на левом боку которого четко обозначены солярные знаки - сферические круговые окружности, а также полузавитые линии, напоминающие букву S в горизонтальном положении. Данные знаки, словно тавро, отсылают нас к древним солярным культам, поклонение которым в рассматриваемый период, видимо, все еще продолжало оставаться актуальным, что и было зафиксировано древними мастерами (фото 18).

В контексте отображения данного символа в искусстве можно отметить, что в течение всего сакского/ скифского периода, а также впоследствии и в первом тысячелетии нашей эры, данные символы, как правило, практически всегда в том или ином виде были представлены в изделиях, относящихся к зооморфному стилю.

Особо следует отметить в этом плане археологические находки 1971-1974 годов, а затем 1998-2004 гг., проведенные в Туве, в результате которых были найдены захоронения царей и знати в «Долине царей», курганах Аржан-1 и Аржан-2, что предоставило исследователям исключительно богатый и разнообразный материал. Были найдены хорошо сохранившиеся захоронения правителя с большим количеством золотых предметов и украшений - почти 2,5 тысяч1. Обнаруженные древние курганы, относящиеся к IX-VIII (Аржан-1) и VII (Аржан-2) вв. до н. э. ${ }^{2}$, позволили сделать Туву, центр Азии, родиной скифов и удревнить их историю в целом. В контексте изучаемой темы найденные ювелирные украшения и военное снаряжение имеют большое значение для понимания характера религиозных верований.

Исключительно яркими и одновременно утонченно изысканными и эстетическими являются ювелирные украшения из кургана Аржан-2. Выполненные настолько искусно, с проработкой мельчайших микро-деталей, данные изделия, словные невесомые свидетели прошлого, показывают нам удивительный талант мастеров прошлого, которое не может не вызывать восхищения.

\footnotetext{
${ }^{1}$ Сокровища Долины царей. Постоянная выставка [Электронный ресурс] // Национальный музей Республики Тыва им. «Алдан-Маадыр». 2017, 2 июня. URL: http://museum.tuva.ru/?p=451 (дата обращения: 02.10.2020).

${ }^{2}$ Как отмечают исследователи, между курганами существует хронологический интервал, когда «Аржан-1 открывает «царский» могильник, а Аржан-2 закрывает его» (Чугунов, 2009: 185).
} 


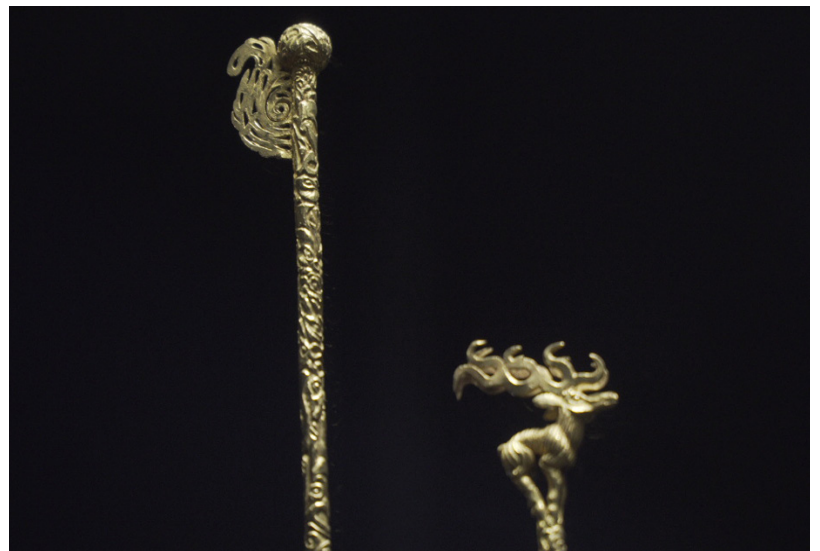

Фото 19. Навершие головного убора в виде фигурки оленя, курган Аржан-2, Тыва. VII в. до н. э. Золото. Фото Тревора Уоллеса; Национального музея им. Алдан-Маадыр Республики Тыва.

Photo 19. The top of a headpiece shaped as a deer figurine from kurgan Arzhan II, Tuva. 7th c. BCE. Gold. Photo by Trevor Wallace,

Aldan Maadyr National Museum of the Republic of Tuva.

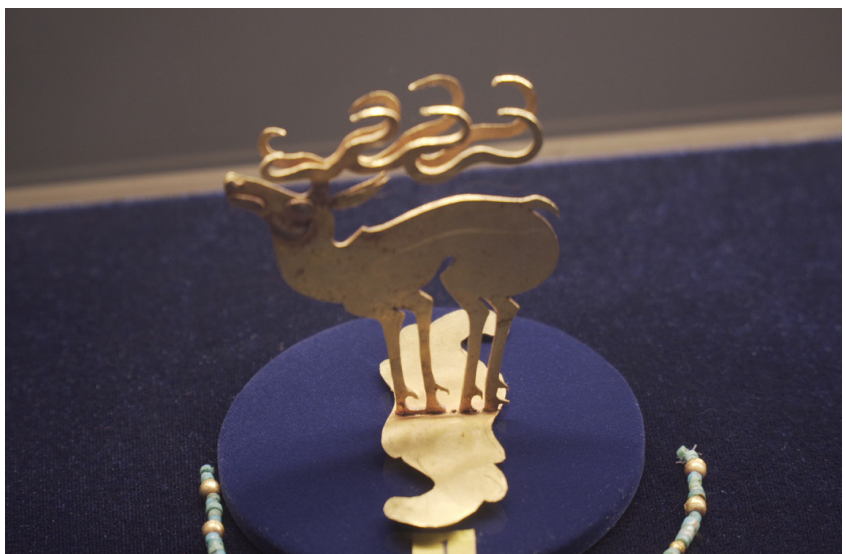

Фото 20. Навершие головного убора в виде плоской фигурки оленя, курган Аржан-2, Тыва. VII в. до н. э. Золото. Фото Тревора Уоллеса; Национального музея им. Алдан-Маадыр Республики Тыва.

Photo 20. The top of a headpiece shaped as a flat deer figurine from kurgan Arzhan II, Tuva. 7th c. BCE. Gold. Photo by Trevor Wallace, Aldan Maadyr National Museum of the Republic of Tuva.

В данных изделиях очень хорошо представлены символические репрезентации солнца в виде специфического нанесения солярных знаков, изогнутых линий, кругов, а также изображения сакральных животных, в частности, оленей и лошадей.

К одним из таких ярких образцов можно отнести изображение оленя на золотой шпильке, которая прикреплялась к вершине головного убора предполагаемой «царицы» (фото 19), а также фигуру оленя, являвшуюся навершием головного убора мужчины-вождя (фото 20).

Изящные фигуры оленей с раскидистыми тяжелыми рогами, словно волнами, уходящими назад,

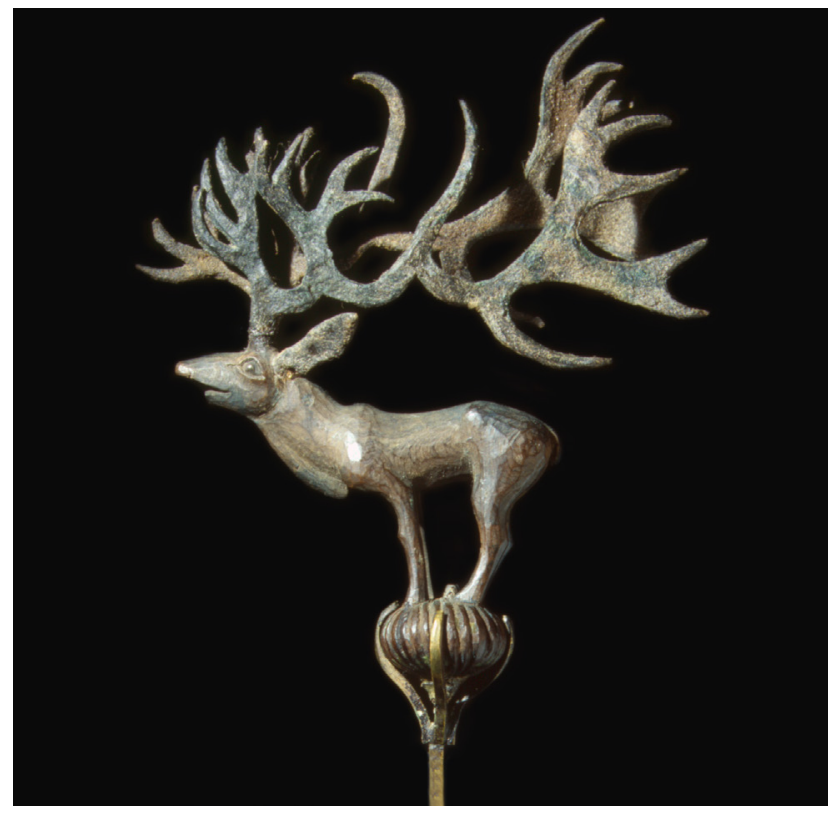

Фото 21. Навершие в виде скульптурной фигурки оленя из Второго Пазырыкского кургана. Рубеж IV-III вв. до н. э. Дерево, кожа. Высота: 12,2 см (наиб.) 1684-153.

Фото А. М. Кокшарова, В. С. Теребенина, Л. Г. Хейфеца.

Фото Государственного Эрмитажа, г. Санкт-Петербург.

Photo 21. A finial shaped as a sculpted deer figurine from the Second Pazyryk mound. Turn of the 3rd c. BCE. Wood and leather. $12.2 \mathrm{~cm}$ max height 1684-153.

Photo by A. M. Koksharov, V. S. Terebenin, L. G. Kheifets, State Hermitage Museum, St. Petersburg. выполнены с большим вкусом, исключительно тонко, эстетично и гармонично. Данные изображения - это апофеоз сакральности, отображения Солнца в виде оленя-солнце как сакрального животного, олицетворявшего собой данное светило. Это также символ торжества и величия правителя, поклоняющегося Солнцу, находящегося под защитой этого важного небесного светила и небес в целом, показывающего свою сакральную связь с ним, в том числе и легитимацию своей власти. В качестве навершия головного убора, данное изображение отсылает нас также и к другому подобному изображению оленя с большими рогами, сделанного из дерева и кожи, найденному во Втором Пазырыкском кургане (V-IV вв. до н. э.). Также как и олени из кургана Аржан, изображение оленя из Пазырыкского кургана представляло собой навершие на головном уборе, при этом ноги оленя, сведенные воедино, опирались на сферу, венчавшую шпильку/стержень, входивший в головной убор (фото 21).

Еще одним интересным артефактом, показывающим сакральность животного-солнца, в частности, лошади-солнца, являются парные золотые пластины в виде симметрично сидящих лошадей, которые прикреплялись на переднюю часть головного убора правителя (фото 22). 


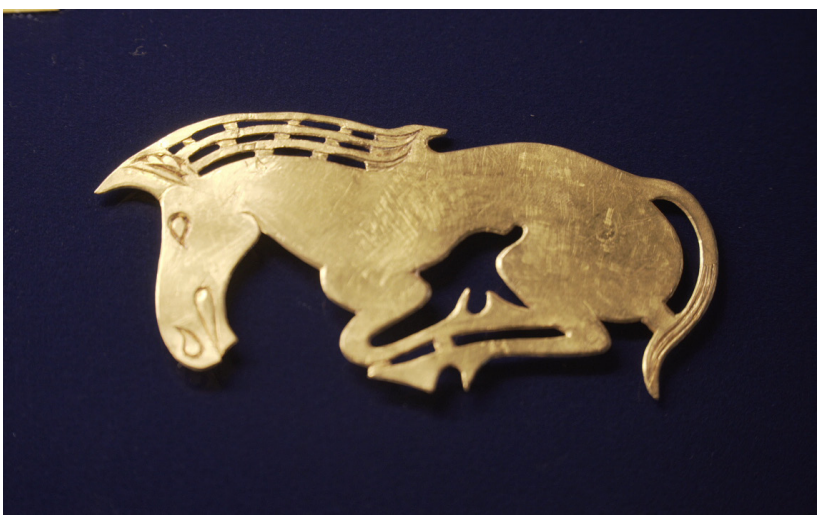

Фото 22. Пластина в виде лошади на головном уборе, курган Аржан-2, Тыва. VII в. до н. э. Золото. Фото Тревора Уоллеса;

Национального музея им. Алдан-Маадыр Республики Тыва. Photo 22. A horse-shaped headpiece plate, kurgan Arzhan II, Tuva, 7th c. BCE. Gold. Photo by Trevor Wallace, Aldan Maadyr National Museum of the Republic of Tuva.

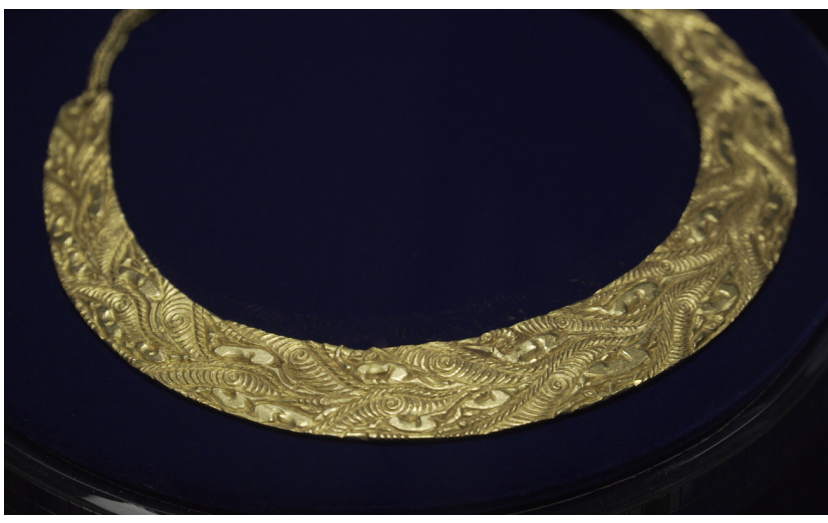

Фото 23. Золотая пектораль, курган Аржан-2, Тыва. VII в. до н. э. Золото. Фото Тревора Уоллеса; Национального музея им. Алдан-Маадыр Республики Тыва.

Photo 23. A golden pectoral, kurgan Arzhan II, Tuva. 7th c. BCE. Gold. Photo by Trevor Wallace, Aldan Maadyr National Museum of the Republic of Tuva.

Данное изображение из кургана Аржан также концептуально выдержано в лаконичном торжественном стиле - оно лишено сцен «терзания» зверей, а предназначено для подчеркивания сакральной роли животного как символической репрезентации солнца, под покровительством которого находился данный правитель.

Об этом же свидетельствуют также форма и детализация золотой пекторали, нагрудного украшения (фото 23).

Многочисленные волнообразные линии-завитки, полукруги и окружности, словно барашки волн, бороздящие водную гладь, с добавлением в пространство между ними небольших фигур животных, также являют собой торжество сакральности солнца. Через насыщенные смыслом солярные символы, данное нагрудное украшение, выполненное на высочайшем техническом уровне, являет собой подлинный шедевр древнесакского искусства, изготовленный неизвестным нам мастером, а в более общем плане - и всего зооморфного стиля, а также символической репрезентации религиозных представлений.

\section{Заключение}

Многочисленные артефакты и находки (бронзовые жертвенники, золотые украшения, нашивки на одежду, элементы конской упряжи, снаряжения), найденные в различных курганах и могильниках, в частности, курганах Аржан-1 и 2, самых древних скифских курганах Евразии (Семенов, 2011), датируемых концом IX - началом VIII в. до н. э. и VII в. до н.э. соответственно, находящихся в Туве, а также находки из захоронений на Алтае (Пазырыкские курганы), в Семиречье (на территории современного южного Казахстана и Кыргызстана) показывают имевшееся религиозное разнообразие и взаимодействие, а также несомненные параллели.

Отстоящие друг от друга географически, тем не менее, данные культурно-исторические ареалы выработали схожие образцы религиозной репрезентации, что позволяет поставить вопрос не только о несомненной близости и взаимодействии племен, проживавших на обширных пространствах Евразии, но также и о типологических закономерностях репрезентации религиозных представлений в древности в целом. Зооморфный стиль в искусстве Центральной Азии является прекрасной возможностью исследовать особенности религиозных представлений людей в древности.

Рассмотренные выше артефакты, относящиеся к сакскому периоду, а в художественном плане к зооморфному стилю искусства, показывают многообразие и переплетение различных религиозных представлений людей, живших во второй половине - середине первого тысячелетия до нашей эры.

Данные представления, проявляемые в их тотальности и взаимосвязанности, очень хорошо показывают направления религиозных верований, которые не только не исключали друг друга, а, наоборот, сосуществовали и соединялись между собой в различных пропорциях, образуя своеобразную религиозную семиосферу. Искусство зооморфного стиля отразило данный религиозный синкретизм 
исключительно ярко, универсально и одновременно самобытно, тонко и эстетично, широко и жизнеутверждающе.

Изученные артефакты хорошо показывают отражение в искусстве таких религиозных верований, как культ Солнца, Неба, предков, тотемизм, магия, шаманизм. Одним из устойчивых и повторяющихся элементов символической репрезентации религиозных верований можно считать (помимо собственно изображений животных, давших название данному стилю) солярный и тотемический символизм, отразившие большую роль, которую играло солнце и окружавший человека животный мир.

Заслуживает внимания трансформация изображения солнца, изначально представлявшегося в виде знака (круга), в символ, насыщенный смыслом и информацией. Солнце как светило предстает в форме символических кругов, к нему отсылает также материал, используемый мастерами - золото. О нем же свидетельствуют и изображения определенных сакральных животных, или животныхсолнце, наподобие оленя-солнце, лося-солнца у древних жителей Сибири (Окладников, Мазин, 1976) или лошади-солнце в степной части Евразии. И, наконец, солярные символы присутствуют на оленных камнях, а также отражают поклонение этому светилу в концептуальной круговой-радиальной структуре курганов-херексуров.

Зооморфные изображения, найденные и относящиеся к сакской/скифской культурам, в методологическом плане можно рассматривать также в качестве определенной стадии/этапа в эволюции религиозных верований, которые отразили эволюцию от знака к символу. В ходе данной эволюции происходила трансформация от конкретного и реалистичного изображения животных к более абстрактному, вплоть до мифического и фантасмагорического, насыщенному разнообразной символикой. При этом в зооморфном стиле, также как и в символе, который включает в себя знак, информацию, смысл, аналогичным образом были соединены религиозные представления, характерные для предыдущих этапов развития социальных групп. В частности, более древние представления, отсылающие к солярным, небесным культам, изначально представали в виде реалистичного изображения солнца, луны, небосвода (на наскальных рисунках). Впоследствии они стали репрезентироваться символически, например, в виде символов солнца, выражаемых через форму (круги, спирали, S знаки, волнистые линии), композицию (херексуры), цвет (желтый, рыжий), животное (олень-, лошадь-, бык-солнце), металл (золото). Данная символика, сохраняясь и передаваясь далее через материальную культуру, могла снижать свое присутствие и значение, но не исключаться вовсе.

В религиозном плане данные репрезентации можно соотнести с наиболее древними религиозными верованиями, связанными с основополагающими представлениями человека о природе - солярными, лунарными, астральными, зооморфными культами, культом предков, магией, анимизмом, фетишизмом, шаманизмом. Поэтому зооморфный стиль в искусстве и материальной культуре можно считать одним из древнейших и всеобъемлющих элементов религиозных представлений в целом.

Таким образом, зооморфные изображения, изначально предстающие в более широком плане как репрезентация и знак, одновременно могут являться также смыслом и символом. Иными словами, они не только могут означать и показывать то или иное животное посредством знака, но и являть его в качестве смысловой интерпретации конкретных явлений на социальном уровне, а также наделять его символикой как отражением определенных представлений на уровне культурной системы. Поэтому зооморфные изображения подобны мощному символическому ряду, несущему исключительно важную нагрузку в системе религиозных представлений, магических ритуалов, защитных и благопожелательных символов.

Поскольку зооморфный стиль одновременно включает в себя и знак, и символ, соответственно, зооморфный стиль в искусстве краток, лаконичен и одновременно объемен, выразителен, вмещает в себя множественную символику, обладает смыслом, значением, несет информацию и определенное знание.

\section{Благодарности}

Автор статьи искренне благодарит коллектив Национального музея Республики Тыва (г. Кызыл) и лично заместителя директора Национального музея Республики Тыва Х. К. Кадыг-оола за предоставленные фотоматериалы из коллекций музея, в частности, относящихся к курганам Аржан-1-2.

Большую благодарность автор выражает руководству и сотрудникам Государственного Эрмитажа (г. Санкт-Петербург) и лично заместителю генерального директора Государственного Эрмитажа, глав- 
ному хранителю С. Б. Адаксиной, О. Ю. Лаптевой, а также специалистам Отдела Востока и Отдела археологии за любезно предоставленные фотографии артефактов, сделанные фотографами А. М. Кокшаровым, В. С. Теребениным, Л. Г. Хейфецем.

Автор приносит большую благодарность главному научному сотруднику Тюркской академии (г. Нур-Султан), д-ру Н. Базылхану за предоставленные фотографии оленных камней из Монголии, сделанные им в ходе проведенных полевых исследований.

\section{СПИСОК ЛИТЕРАТУРЫ}

Акишев, К. А. (1978) Курган Иссык. Искусство саков Казахстана. М. : Искусство. 132 с.

Грач, А. Д. (1955) Каменные изваяния западной Тувы (к вопросу о погребальном ритуале тугю) // Сборник музея антропологии и этнографии. Т. XVI. М. ; Л. : Издательство АН СССР. С. 401-431.

Килуновская, М. Е. (2018) Археологические памятники на границе Тувы и Монголии (проблемы культурной принадлежности и хронологии) // Научное обозрение Саяно-Алтая. № 1 (21). С. 35-54.

Килуновская, М. Е., Семенов, Вл. А. (2019) Искусство древней Тувы (III-I тысячелетия до н. э.) // Искусство Евразии. № 3 (14). С. 20-49. DOI: https://www.doi.org/10.25712/ASTU.2518-7767.2019.03.002

Кисель, В. А. (2019) Погребальное убранство из кургана Аржан-2: декор, технологии, авторство // Сатеra Praehistorica. № 2 (3). C. 93-122. DOI: https://www.doi.org/10.31250/2658-3828-2019-2-93-122

Кореняко, В. А. (2002) Искусство народов Центральной Азии и звериный стиль. М. : Издательская фирма «Восточная литература» РАН. 327 с.

Лотман, Ю. М. (1999) Внутри мыслящих миров. Человек - текст - семиосфера - история. М. : Языки русской культуры. 464 с.

Маннай-оол, М. Х. (1970) Тува в скифское время (Уюкская культура). М. : ГРВЛ. 122 с.

Нурмуханбетов, Б. Н., Тулегенов, Т. Ж., Иванов, С. С. (2019) Коллекция предметов вооружения сакского времени из могильников Молалы и Шубарат // Теория и практика археологических исследований. № 1 (25). C. 99-108. DOI: https://www.doi.org/10.14258/tpai(2019)1(25).-09

Окладников, А. П. (1989) [1964] Олень Золотые Рога. Рассказы об охоте за наскальными рисунками. Открытие Сибири. Главы из книги. Хабаровск : Книжное издательство. 208 с.

Окладников, А. П., Мазин, А. И. (1976) Писаницы реки Олекмы и Верхнего Приамурья. Новосибирск : Наука, Сибирское отделение. 189 с.

Руденко, С. И. (1953) Культура населения Горного Алтая в скифское время. М. ; Л. : Изд-во АН СССР. 402 с. + 120 табл.

Руденко, С. И. (1962) Сибирская коллекция Петра I / Свод археологических источников, САИ Д3-9. М. ; Л. : Издво АН СССР. 52 с. +27 табл.

Сарианиди, В. А. (1983) Афганистан: сокровища безымянных царей. М. : Главная редакция восточной литературы. 159 с.

Семенов, В. А. (2011) Искусство скифов на севере Центральной Азии // Научные труды. № 17. С. 3-20.

Толстякова, С. П. (2019) Ритуальная атрибутика в эпическом сюжете Олонхо // Тенгрианство и эпическое наследие народов Евразии: истоки и современность»: сборник статей VII Международной научно-практической конференции (21-22 июня 2019 г., Бишкек, Кыргызстан). Бишкек : Алтын тамга. 360 с. с. 263-266.

Ховалыг, Р. Б., Хорлуштай, Ш. Р., Дамба, А. В., Ооржак, В. Д. (2019) Реконструкция образов «царя» и «царицы» из кургана Аржан-2: особенности, проблемы, пути их решения // Oriental Studies. № 5 (45). C. 799-811. DOI: https:// www.doi.org/10.22162/2619-0990-2019-45-5-799-811

Чугунов, К. В. (2002) Херексуры Центральной Азии (к вопросу об истоках традиции) // Северная Евразия в эпоху бронзы: пространство, время, культура : сборник научных работ / под ред. Ю. Ф. Кирюшина, А. А. Тишкина. Барнаул : Изд-во Алт. ун-та. 230 с. С. 142-149.

Чугунов, К. В. (2009) Аржан-1 и Аржан-2: сравнительный анализ [Электронный ресурс] // Новые исследования Тувы. № 3. С. 176-186. URL: https://nit.tuva.asia/nit/article/view/637 (дата обращения: 13.11.2020).

Чугунов, К. В. (2020) Маркеры культурно-хронологических горизонтов раннескифского времени в азиатской зоне степей Евразии - опыт выделения // Древние и средневековые культуры Центральной Азии (становление, развитие и взаимодействие урбанизированных и скотоводческих обществ): Материалы Международной конференции, посвященной 100-летию со дня рождения д. и. н. А. М. Мандельштама и 90-летию со дня рождения 
д. и. н. И. Н. Хлопина (10-12 ноября 2020 г., Санкт-Петербург) / отв. ред. В. П. Никоноров, Л. Б. Кирчо, Е. О. Стоянов. СПб.: ИИМК РАН, 2020. 308 с., ил. С. 229-231. DOI: 10.31600/978-5-907298-09-5-229-231

Шульга, П. И. (2013) Особенности угасания и трансформации раннескифских культур в VI в. до н.э. на востоке Евразии (к постановке проблемы) // Вестник Томского государственного университета. История. № 3 (23). C. 319-323.

Cambon, P., Jarrige, J.-F. (Eds) (2006) Afghanistan. Les tresors retrouves. Collections du musee national de Kaboul. Paris : Musee national des arts asiatiques-Guimet. 299 p.

Frumkin, G. (1964) Archaeology in Soviet Central Asia. III Kirgiziya and the Fergana Valley // Central Asian Review. Vol. XII, № 1. P. 16-29.

Kilunovskaya, M., Semyonov, V. (2019) Ancient Cultures of Tuva and Its Environment in 4th-1st Millennia BC // Восточный курьер. № 1-2. С. 30-61. DOI: https://www.doi.org/10.18254/S268684310007885-6-1

Parsons, T. (1985) On Institutions and Social Evolution. Selected Writings. Ed. and Introduction by Leon H. Mayhew / The Heritage of Sociology Series. Chicago ; London : The University of Chicago Press. 356 p.

Shao, C. (2000) L'ancienne civilization nomade des steppes du nord de la Chine // L’Asie des steppes d'Alexandre le Grand a Gengis Khan / Jean-Paul Desroches. Paris ; Barcelone : la Reunion des musees nationaux/Musee national des Arts asiatiques-Guimet, la Fundacio «la Caixa». 202 p. P. 17-29.

Turbat, Ts., Batsukh, D. (2015) L’art dans la culture de Pazyryk et ses manifestations dans l'Altai Mongol // FranceMongolie: Decouvertes archeologiques. Vingt ans de partenariat. Sous la direction de P.-H. Giscard, T. Turbat. Catalogue de l'exposition. Ulaanbaatar : Institut d'Histoire et d'Archeologie. 176 p. P. 33-39.

Дата поступления: 17.12.2020 г.

\section{REFERENCES}

Akishev, K. A. (1978) Kurgan Issyk. Iskusstvo sakov Kazakhstana [Kurgan Issyk. Art of the Saks of Kazakhstan]. Moscow, Iskusstvo. 132 p. (In Russ.).

Grach, A. D. (1955) Kamennye izvaianiia zapadnoi Tuvy (K voprosu o pogrebal'nom rituale tugiu) [Stone statues of the West Tuva: on the Tugu burial ritual]. In: Sbornik Muzeya antropologii i etnografii [The Collection of the Museum of Anthropology and Ethnography]. Vol. XVI. 461 p. Pp. 401-431. (In Russ.)

Kilunovskaya, M. E. (2018) Arkheologicheskie pamiatniki na granitse Tuvy i Mongolii (problemy kul'turnoi prinadlezhnosti i khronologii) [Archaeological sites on the border of Tuva and Mongolia (problems of cultural affiliation and chronology)]. Nauchnoe obozrenie Saiano-Altaia, no. 1 (21), pp. 35-54. (In Russ.).

Kilunovskaya, M. E. and Semenov, Vl. A. (2019) Iskusstvo drevnei Tuvy (III-I tysiacheletiia do n. e.) [Art of ancient Tuva ( $3^{\text {rd }}-1^{\text {st }}$ millennium BC)]. Iskusstvo Evrazii, no. 3 (14), pp. 20-49. (In Russ.). DOI: https://www.doi.org/10.25712/ ASTU.2518-7767.2019.03.002

Kisel, V. A. (2019) Pogrebal'noe ubranstvo iz kurgana Arzhan-2: dekor, tekhnologii, avtorstvo [Funeral paraphernalia from kurgan Arzhan-2: decor, technologies, authorship]. Camera Praehistorica, no. 2 (3), pp. 93-122. (In Russ.). DOI: https://www.doi.org/10.31250/2658-3828-2019-2-93-122

Koreniako, V. A. (2002) Iskusstvo narodov Tsentral'noi Azii i zverinyi stil' [The art of the peoples of Central Asia and the Animal style]. Moscow, Vostochnaia literatura RAN Publ. 327 p. (In Russ.).

Lotman, Yu. M. (1999) Vnutri mysliashchikh mirov. Chelovek - tekst - semiosfera - istoriia [Inside the Thinking Worlds. Man - text - semiosphere-history]. Moscow, Yazyki russkoi kul'tury. 464 p. (In Russ.).

Mannaj-ool, M. H. (1970) Tuva v skifskoe vremia (Uyukskaia kul'tura) [Tuva in Scythian time: the Uyuk culture]. Moscow, Nauka. 117 p. (In Russ.)

Nurmukhanbetov, B. N., Tulegenov, T. Zh. and Ivanov, S. S. (2019) Kollektsiia predmetov vooruzheniia sakskogo vremeni iz mogil'nikov Molaly i Shubarat [The collection of weapon of the Saka period from the Shubarat and Molaly burial mounds]. Teoriia i praktika arkheologicheskikh issledovanii, no. 1 (25), pp. 99-108. (In Russ.). DOI: https://www.doi. org/10.14258/tpai(2019)1(25).-09

Okladnikov, A. P. (1989) [1964] Olen' Zolotye Roga. Rasskazy ob okhote za naskal'nymi risunkami. Otkrytie Sibiri. Glavy iz knigi [The Deer with Golden Antlers: Stories about hunting for rock paintings. The discovery of Siberia. Chapters from the book]. Khabarovsk, Knizhnoe izdatel'stvo. 208 p. (In Russ.).

Okladnikov, A. P. and Mazin, A. I. (1976) Pisanitsy reki Olekmy i Verkhnego Priamur'ia [The writings of the Olekma River and the Upper Amur region]. Novosibirsk, Nauka, Sibirskoe otdelenie. 189 p. (In Russ.). 
Rudenko, S. I. (1953) Kul'tura naseleniia Gornogo Altaia v skifskoe vremia [Culture of the population of the Mountain Altai in the Scythian times]. Moscow, Leninrgad, Izd-vo AN SSSR. 402 p. + 120 tabl. (In Russ.).

Rudenko, S. I. (1962) Sibirskaia kollektsiia Petra I / Svod arkheologicheskikh istochnikov, SAI D3-9 [The Siberian collection of Peter the Great / A compilation of archaeological sources, SAI D3-9]. Moscow, Leningrad, Izd-vo AN SSSR. 52 p. + 27 tabl. (In Russ.).

Sarianidi, V. A. (1983) Afganistan: sokrovishcha bezymiannykh tsarei [Afghanistan: treasures of the nameless kings]. Moscow, Glavnaia redaktsiia vostochnoi literatury. 159 p. (In Russ.).

Semenov, V. A. (2011) Iskusstvo skifov na severe Tsentral'noi Azii [Scythian art in the North of Central Asia]. Nauchnye Trudy, no. 17, pp. 3-20. (In Russ.).

Tolstiakova, S. P. (2019) Ritual'naia atributika v epicheskom siuzhete Olonkho [Ritual accessories in the epic plot of Olonkho]. In: Tengrianstvo i epicheskoe nasledie narodov Evrazii: istoki i sovremennost' [Tengrianism and the epic heritage of the peoples of Eurasia: origins and modernity]: collection of articles of the $7^{\text {th }}$ international research conference (June 21-22, 2019, Bishkek, Kyrgyzstan). Bishkek, Altyn tamga. 360 p. Pp. 263-266. (In Russ.).

Khovalyg, R. B., Khorlushtai, Sh. R., Damba, A. V. and Oorzhak, V. D. (2019) Rekonstruktsiia obrazov «tsaria» i «tsaritsy» iz kurgana Arzhan-2: osobennosti, problemy, puti ikh resheniia [Reconstructing Images of 'King' and 'Queen' from Arzhan-2 Mound: Features, Problems, Solutions]. Oriental Studies, no. 5 (45), pp. 799-811. (In Russ.). DOI: https://www. doi.org/10.22162/2619-0990-2019-45-5-799-811

Chugunov, K. V. (2002) Khereksury Tsentral'noi Azii (k voprosu ob istokakh traditsii) [The Khereksurs of Central Asia: the origins of tradition)]. In: Severnaia Evraziia v epokhu bronzy: prostranstvo, vremia, kul'tura [Northern Eurasia in the Bronze Age]: space, time, culture : a collection of articles / ed. by Yu. F. Kiriushin and A. A. Tishkin. Barnaul, Izd-vo Alt. un-ta. 230 p. Pp. 142-149. (In Russ.).

Chugunov, K. V. (2009) Arzhan-1 i Arzhan-2: sravnitel'nyi analiz [Arzhan-1 and Arzhan-2: a comparative analysis]. New Research of Tuva, no. 3, pp. 176-186 [online] Available at: https://nit.tuva.asia/nit/article/view/637 (access date: 13.11.2020). (In Russ.).

Chugunov, K. V. (2020) Markery kul'turno-khronologicheskikh gorizontov ranneskifskogo vremeni v aziatskoi zone stepei Evrazii - opyt vydeleniia [Markers of cultural and chronological horizons of the Early Scythian time in the Asian zone of the Eurasian steppes: the experience of selection]. In: Drevnie i srednevekovye kul'tury Tsentral'noi Azii (stanovlenie, razvitie i vzaimodeistvie urbanizirovannykh i skotovodcheskikh obshchestv) [Ancient and medieval cultures of Central Asia: formation, development and interaction of urbanized and pastoral societies]: Proceedings of the International Conference dedicated to the 100th anniversary of the birth of Doctor of Historical Sciences A. M. Mandelstam and the 90th anniversary of the birth of Doctor of Historical Sciences I. N. Khlopin (November 10-12, 2020, St. Petersburg) / ed. by V. P. Nikonorov, L. B. Kircho and E. O. Stoianov. St. Petersburg, IIMK RAN. 308 p., il. Pp. 229-231. (In Russ.). DOI: https://www.doi. org/10.31600/978-5-907298-09-5-229-231

Shul'ga, P. I. (2013) Osobennosti ugasaniia i transformatsii ranneskifskikh kul'tur v VI v. do n.e. na vostoke Evrazii (k postanovke problemy) [Special features of decline and transformation of the early Scythian cultures in the sixth century b.c. in the East of Eurasia (defining the problem)]. Vestnik Tomskogo gosudarstvennogo universiteta. Istoriia, no. 3 (23), pp. 319-323. (In Russ.).

Cambon, P. and Jarrige, J.-F. (Eds) (2006) Afghanistan. Les tresors retrouves. Collections du musee national de Kaboul. Paris, Musee national des arts asiatiques-Guimet. 299 p.

Frumkin, G. (1964) Archaeology in Soviet Central Asia. III Kirgiziya and the Fergana Valley. Central Asian Review, vol. XII, no. 1, pp. 16-29.

Kilunovskaya, M. and Semyonov, V. (2019) Ancient Cultures of Tuva and Its Environment in 4th-1st Millennia BC. Vostochnyi kur'er, no. 1-2, pp. 30-61. DOI: https://www.doi.org/10.18254/S268684310007885-6-1

Parsons, T. (1985) On Institutions and Social Evolution. Selected Writings. Ed. and Introduction by Leon H. Mayhew / The Heritage of Sociology Series. Chicago; London, The University of Chicago Press. 356 p.

Shao, C. (2000) L'ancienne civilization nomade des steppes du nord de la Chine. In: L'Asie des steppes d'Alexandre le Grand a Gengis Khan / Jean-Paul Desroches. Paris; Barcelone, la Reunion des musees nationaux/Musee national des Arts asiatiques-Guimet, la Fundacio «la Caixa». 202 p. Pp. 17-29.

Turbat, Ts. and Batsukh, D. (2015) L'art dans la culture de Pazyryk et ses manifestations dans l'Altai Mongol. In: FranceMongolie: Decouvertes archeologiques. Vingt ans de partenariat. Sous la direction de P.-H. Giscard, T. Turbat. Catalogue de l'exposition. Ulaanbaatar, Institut d'Histoire et d'Archeologie. 176 p. Pp. 33-39.

Submission date: 17.12 .2020 . 